\title{
Investigation of Environmentally Assisted Fracture of Metallic Nuclear Waste Package Barrier Materials in Simulated Basalt Repository Environments
}

\author{
S. G. Pitman
}

November 1982

Prepared for the U.S. Department of Energy under Contract DE-AC06-76RLO 1830

Pacific Northwest Laboratory Operated for the U.S. Department of Energy by Battelle Memorial Institute 


\title{
DISCLAIMER
}

This report was prepared as an account of work sponsored by an agency of the United States Government. Neither the United States Government nor any agency thereof, nor any of their employees, makes any warranty, express or implied, or assumes any legal liability or responsibility for the accuracy, completeness, or usefulness of any information, apparatus, product, or process disclosed, or represents that its use would not infringe privately owned rights. Reference herein to any specific commercial product, process, or service by trade name, trademark, manufacturer, or otherwise, does not necessarily constitute or imply its endorsement, recommendation, or favoring by the United States Government or any agency thereof. The views and opinions of authors expressed herein do not necessarily state or reflect those of the United States Government or any agency thereof.

\author{
PACIFIC NORTHWEST LABORATORY \\ operated by \\ BATTELLE \\ for the \\ UNITED STATES DEPARTMENT OF ENERGY \\ under Contract DE-AC06-76RLO 1830
}

Printed in the United States of America Available from

National Technical Information Service United States Department of Commerce

5285 Port Royal Road

Springfield, Virginia 22151

NTIS Price Codes

Microfiche A01

Printed Copy

$\begin{array}{ll}\text { Pages } & \text { Price } \\ \text { Codes }\end{array}$

001-025

026-050

051-075

076-100

$101-125$

126-150

$151-175$

176-200

201-225

226-250

251-275

Codes

276-300

$\mathrm{A} 02$
$\mathrm{~A} 03$
$\mathrm{~A} 04$
$\mathrm{~A} 05$
$\mathrm{~A} 06$
$\mathrm{~A} 07$
$\mathrm{~A} 08$
$\mathrm{~A} 09$
$\mathrm{~A} 010$
$\mathrm{~A} 011$
$\mathrm{~A} 012$
$\mathrm{~A} 013$


S. G. Pitman

November 1982

Prepared for

the U.S. Department of Energy

under Contract DE-AC06-76RLO 1830

Pacific Northwest Laboratory

Richland, Washington 99352 
v 


\section{ACKNOWLEDGMENTS}

Thanks are extended to D. M. Squier, Jr., for performing the slow strain rate tests; to S. M. Faber for conducting the fatigue crack growth rate tests; and to H. E. Kjarmo, for fractography. The administrative and technical assistance of R. E. Westerman, project leader, was especially helpful. The assistance of S. K. Edler in the preparation of this document is also appreciated. 
$+$ 


\section{SUMMARY AND CONCLUSIONS}

Statically loaded corrosion tests, slow strain rate (SSR) tests, and fatigue crack growth rate (FCGR) tests have been conducted by Pacific Northwest Laboratory (PNL) to evaluate the relative susceptibility of two titanium-base nuclear waste package candidate structural barrier materials-Ti-grade 2 and Ti-grade 12--to environmentally enhanced cracking in a simulated repository environment. Statically loaded corrosion tests were done in oxic basalt ground water (a) at $250^{\circ} \mathrm{C}$; SSR tests were done in oxic basalt ground water at $150^{\circ} \mathrm{C}, 250^{\circ} \mathrm{C}$, and $300^{\circ} \mathrm{C}$ and in air at $20^{\circ} \mathrm{C}$ and $250^{\circ} \mathrm{C}$; and FCGR tests were done in basalt ground water, fluoride-ion-enhanced basalt ground water, high-purity water, and air at $90^{\circ} \mathrm{C}$. This document summarizes results of previous tests and presents data from recent tests. From the results obtained to date, the following conclusions can be drawn:

- The general corrosion rate of statically loaded corrosion coupons was very low in a 3-mo test, and no pitting or cracking of the specimens was observed.

- Ti-grade 2 and Ti-grade 12 exhibited strain rate dependent ductility diminution in SSR tests.

- The ductility diminution was most severe in Ti-grade 2 at $300^{\circ} \mathrm{C}$ and in $\mathrm{Ti}$-grade 12 at $250^{\circ} \mathrm{C}$.

- The ductility diminution of Ti-grade 12 was found to be highly orientation dependent. (Only one orientation of Ti-grade 2 was tested.)

- The ductility diminution was also found in tests conducted in air as well as in those conducted in the basalt ground water environment; however, the extent of the degradation was less in air.

(a) The term "basalt ground water" describes a simulated ground water representative of the Columbia Plateau Basalt Region (Rockwell Hanford Operations 1980). The term "oxic" indicates that the ground water has a dissolved oxygen concentration equivalent to that expected if the ground water were in equilibrium with the air. 
- The ductility diminution cannot be attributed to stress corrosion cracking ( SCC) because the fracture mode was microvoid coalescence in all tests.

- Evidence obtained in the current study and correlation of the present results with results obtained by other researchers indicate that dynamic strain aging is responsible for the loss of ductility. It is suggested that environmental effects are caused by breakdown of the passivating $f i l m$ and subsequent diffusion of interstitials into the metal, causing the degree of dynamic strain aging to increase with decreasing strain rate.

- The FCGR of Ti-grade 2 and Ti-grade 12 was not affected by any of the environmental conditions used in this study, which indicates that no environmental cracking mechan ism is operative under the conditions tested $\left(90^{\circ} \mathrm{C}\right.$, oxic ground water, and frequencies from 0.01 to $5 \mathrm{~Hz}$ ). 


\section{CONTENTS}

\section{ACKNOWLEDGMENTS}

SUMMARY AND CONCLUSIONS

INTRODUCT ION

BACKGROUND

EXPERIMENTAL METHODS AND MATERIALS

STATICALLY LOADED CORROSION TESTS

i i i

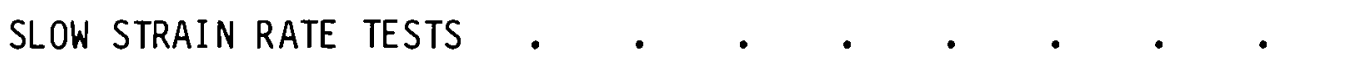

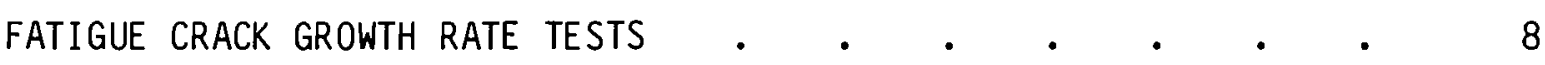

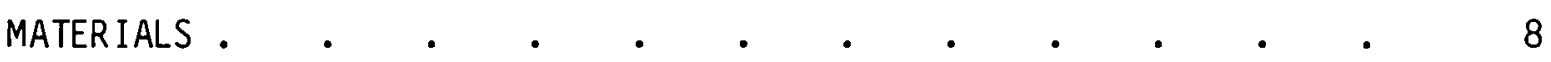

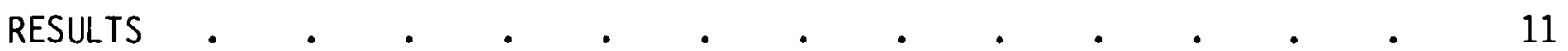

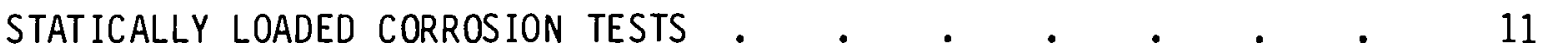

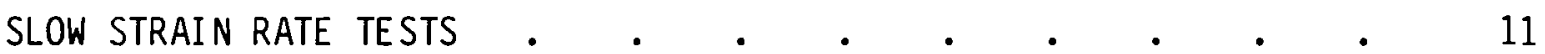

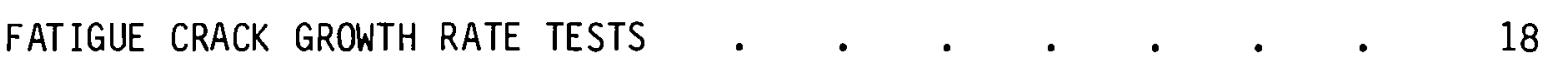

DISCUSSION

REFERENCES 


\section{FIGURES}

1 Slow Strain Rate Testing System . . . . . . . 7

2 Fatigue Crack Growth Rate Testing System . . . . . . 9

3 Reduction of Area and Elongation of Ti-Grade 2 ( $L T$ orientation) in Basalt Ground Water at $150^{\circ} \mathrm{C}$ and $300^{\circ} \mathrm{C} . . .5 .13$

4 Reduction of Area and Elongation of $T i-G r a d e ~ 2$ ( $L T$ orientation) in Basalt Ground Water and Air at $250^{\circ} \mathrm{C}$. . . . . . 13

5 Reduction of Area and Elongation of $T i-G r a d e ~ 2$ ( $L T$ or ientation) as a Function of Temperature . . . . . . . . . 14

6 Reduction of Area and Elongation of Ti-Grade 12 (LT orientation) in Basalt Ground Water at $150^{\circ} \mathrm{C}$ and $300^{\circ} \mathrm{C} . . . \quad . \quad . \quad 14$

7 Reduction of Area and Elongation of Ti-Grade 12 (LT orientation) in Basalt Ground Water and Air at $250^{\circ} \mathrm{C}$. . . . . .

8 Reduction of Area and Elongation of Ti-Grade 12 (LT orientation) as a Function of Temperature . . . . . . . . .

9 Reduction of Area and Elongation of Ti-Grade 12 (TL orientation) in Basalt Ground Water at $150^{\circ} \mathrm{C}$ and $300^{\circ} \mathrm{C} . . . .$.

10 Reduction of Area and Elongation of Ti-Grade 12 ( $T L$ or ientation) in Basalt Ground Water and Air at $250^{\circ} \mathrm{C}$. . . . . . 17

11 Reduction of Area and Elongation of Ti-Grade 12 ( $T L$ or ientation) as a Function of Temperature . . . . . . . .

12 Fracture Surfaces of $T i$-Grade 2 Specimens (LT or ientation)

Strained to Failure in Basalt Ground Water at $250^{\circ} \mathrm{C}$. .

13 Fatigue Crack Growth Rate of Ti-Grade 12 (LT orientation)

Tested at $0.1 \mathrm{~Hz}$ in Fluoride-Ion-Enhanced Basalt Ground

Water and High-Purity Water at $90^{\circ} \mathrm{C}$. . . . . . 20

14 Fatigue Crack Growth Rate of Ti-Grade 12 (TL orientation)

Tes ted at $0.1 \mathrm{~Hz}$ in Fluoride-I on-Enh anced Basalt Ground

Water and High-Purity water at $90^{\circ} \mathrm{C}$

15 Fatigue Crack Growth Rate of Ti-Grade 2 (TL orientation) Tested at $1 \mathrm{~Hz}$ in Basalt Ground Water and at $0.1 \mathrm{~Hz}$ in Fluoride-IonEnh anced Ground Water at $90^{\circ} \mathrm{C}$. 
16 Fatigue Crack Growth Rate of Ti-Grade 12 (LT orientation) Tested at $1 \mathrm{~Hz}$ in Basalt Ground Water and at $0.1 \mathrm{~Hz}$ in Fluoride-IonEnhanced Ground Water at $90^{\circ} \mathrm{C}$.

17 Summary of Strain Rate Effects in Ti-Grade 2 (LT orientation) . . . . . . . . . .

18 Summary of Strain Rate Effects in Ti-Grade 12 (TL orientation)

\section{TABLES}

1 Composition of Basalt Ground Water . . . . . . .

2 Composition of Ti-Grade 2 and Ti-Grade 12 Used in This Study and ASTM Nominal Compositions . . . . . . 10

3 Room Temperature Mechanical Properties of Ti-Grade 2 and Ti-Grade 12 
. 


\section{INTRODUCTION}

An effort to select and characterize materials for licensable engineered barrier systems for long-term containment of nuclear wastes has been under way at Pacific Northwest Laboratory (PNL) ${ }^{(a)}$ since January 1979. The effort is currently funded by the Office of Nuclear Waste Isolation (ONWI) as the Structural Barrier Development Task of the PNL Was te Package Program. The objective of the task is to characterize and recommend materials suitable for use as structural barriers (for example, canisters, overpacks, or hole sleeves) in a was te package capable of maintaining radioisotope release rates at near-zero values for $\sim 1000 \mathrm{yr}$.

Past work in related PNL programs has involved corrosion and material property screening tests of $\sim 20$ metals, $\sim 15$ ceramic materials, and $\sim 30$ polymeric materials (Westerman 1980). These studies included corrosion testing of metals and ceramics, thermal- and radiation-degradation testing of polymers, mechanical and fracture toughness testing of titanium, and preliminary environmentalmechanical testing of titanium. Subsequent work has focused on the most promising materials from the screening studies: Ti-grade 2, Ti-grade 12, ductile cast iron, and low-alloy cast steels.

Current work in the Structural Barrier Development Task involves long-term general corrosion testing, irradiation-corrosion testing, and environmentally assisted fracture testing. (b) Initial results obtained for the first two areas (general corrosion and irradiation-corrosion tests) have been published (Westerman, Pitman, and Nelson 1982).

This report discusses the environmentally assisted fracture testing of Ti-grade 2 and Ti-grade 12, primarily by slow strain rate (SSR) tests and fatigue crack growth rate (FCGR) tests. Background information pertinent to

(a) Operated for the U.S. Department of Energy (DOE) by Battelle Memorial Ins titute.

(b) The term "environmentally assisted fracture" collectively describes degradation mechanisms such as stress corrosion cracking (SCC), hydrogen embrittlement, hydriding, and various forms of metallurgical embrittlement that may be related to the presence of stress and an aggressive environment. 
the environmentally assisted fracture of these materials is presented, and the materials studied and the experimental methods used are described. Results of recent tests and summaries of earlier tests are presented and discussed, with emphas is on results that could affect material selection and design. 


\section{BACKGROUND}

The environmentally enhanced propagation of cracks from pre-existing defects or flaws is one of the potentially most damaging failure modes for was te package structural barrier materials. In susceptible materials, failure from crack propagation can occur in the absence of general corrosion at stresses. well below the general yield strength. This failure mode is also the most difficult to quantify because of the normally long initiation times, the difficulty in detecting minor amounts of crack growth, and its generally unpredictable nature. The approach taken in this investigation uses statically loaded corrosion tests with U-bends and wedge-opening load (WOL) specimens, SSR tests, and environmental FCGR tests.

In the statically loaded corrosion tests, a static load (or, equivalently, a fixed strain) is applied to the specimens prior to their exposure in the test medium. After the test, the weight change of the U-bend specimens is measured, and the U-bend and WOL specimens are examined for pitting and cracking.

In the SSR tests, a tensile specimen is strained to failure at a constant strain rate in the presence of the service environment or an environment representative of the service environment. The deformation of the specimen and the imposed load are continually measured and recorded. Environmentally enhanced fracture is often found to be influenced by strain rate. At high strain rates, the influence of the environment is limited by the time of exposure. At very low strain rates, the oxide film is able to reform during straining so that environment-base metal interaction is again 1 imited. The lowest ductility is often found in tests conducted at intermediate loading rates where interaction between the metal and the environment occurs as the passivating film is broken.

In SSR testing, susceptibility of metals to environmentally enhanced fracture is indicated if one or more of the following phenomena are observed:

- Ductility is lower in the service environment than in an innocuous environment.

- Ductility is influenced by strain rate. 
- Fractographic evidence of an environmentaliy enhanced fracture mode(s) exists; for example, an anomalous cleavage fracture.

When sensitivity of ductility to environment or strain rate is observed, the mode of failure is determined by examining the fracture surfaces. If the mode of failure is not influenced by the presence of the environment, the ductility diminution cannot be attributed to a specific mechan ism of environmentally enhanced fracture (Payer, Berry, and Boyd 1976).

The effects of an aggressive environment on FCGRs are determined from methods analogous to those used in SSR tests: If a frequency dependence or an accelerated crack growth rate relative to an innocuous environment is observed, environmentally enhanced fracture is suspected. The mechanism of crack growth rate acceleration must be determined by examining the fracture surface.

SSR and FCGR tests are considered conservative tests for determining relative susceptibility to environmentally enhanced fracture. These tests use an actively loaded specimen, where the surface corrosion film is broken and fresh metallic material is continually exposed to the environment. The FCGR test is particularly severe because of the combination of a pre-existing sharp crack, continual plastic straining at the crack tip, and the presence of high triaxial stresses (in thick specimens). The loading conditions imposed on specimens are not intended to simulate loading conditions expected in repositories but to provide severe tests of susceptibility to environmentally enhanced fracture. 


\section{EXPERIMENTAL METHODS AND MATERIALS}

The experimental methods and materials used for environmentally ass isted fracture testing are essentially the same as those reported previously; for detailed descriptions of methods, materials, and preliminary environmentalmechanical test results, see Westerman (1980) and Pitman (1981). The statically loaded corrosion, SSR, and FCGR test procedures are briefly described in this section of the report.

\section{STATICALLY LOADED CORROSION TESTS}

Two types of corrosion tests were used for initial evaluations of susceptibility to environmentally enhanced fracture: U-bend tests and WOL tests. In the U-bend tests, material was used that contained a simulated weld bead that was made by melting the material using a tungsten-inert gas ( $T$ IG) welding torch. The $3 / 4 \times 4-1 / 2-i n$. samples were bent into U-bends using the two-stage stressing method described in ASTM G30-72. The samples were insulated from the stressing bolts by alumina washers.

WOL tests were conducted on precracked 1/2-in. thick specimens. The specimens were stressed in a screw-driven testing machine to a high stress intensity $\left(\sim 50 \mathrm{ksi} \sqrt{i_{1}}\right)$, and wedges were inserted to maintain the stress intensity when the specimens were removed from the machine. In this type of specimen, the opening at the crack mouth is maintained at a constant value during the test; thus, the stress intensity remains constant unless crack extension occurs.

The U-bend and WOL specimens were exposed to basalt ground water at $250^{\circ} \mathrm{C}$. Inlet ground water at $\sim 6-\mathrm{ppm}$ dissolved oxygen flowed through crushed basalt at about $30 \mathrm{ml} / \mathrm{h}$ before reaching the specimens. The test duration was 89 days for the WOL specimens and 270 days for the U-bend specimens. The composition of the inlet solution is given in Table 1 .

\section{SLOW STRAIN RATE TESTS}

SSR tests were conducted using tensile specimens fabricated from sheet material. Gage marks inscribed at 1.00-in. intervals on the specimens were 
TABLE 1. Composition of Basalt Ground Water(a)

\begin{tabular}{|c|c|c|}
\hline \multirow[b]{2}{*}{ Chemical Species } & \multicolumn{2}{|c|}{ Concentration, $\mathrm{mg} / \mathrm{l}$} \\
\hline & $\begin{array}{c}\text { Statically Loaded } \\
\text { Corrosion Tests } \\
\end{array}$ & $\begin{array}{l}\text { FCGR and } \\
\text { SSR Tests }\end{array}$ \\
\hline $\mathrm{Na}^{+}$ & 139 & 250 \\
\hline $\mathrm{K}^{+}$ & 13 & 1.9 \\
\hline $\mathrm{Ca}^{+2}$ & 1.6 & 1.3 \\
\hline $\mathrm{Mg}^{+2}$ & 0.5 & 0.4 \\
\hline $\mathrm{CO}_{3}^{-2}$ & & 27 \\
\hline $\mathrm{HCO}_{3}^{-}$ & $167^{(b)}$ & 70 \\
\hline $\mathrm{OH}^{-}$ & 32 & 1.4 \\
\hline $\mathrm{H}_{3} \mathrm{SiO}_{4}^{-}$ & 36 & 103 \\
\hline $\mathrm{Cl}^{-}$ & 52 & 148 \\
\hline $\mathrm{SO}_{4}^{-2}$ & 0.8 & 108 \\
\hline $\mathrm{F}^{-\top}$ & 8 & 37 \\
\hline
\end{tabular}

(a) Target makeup composition; actual compositions varied slightly.

(b) Total $\mathrm{CO}_{3}$.

used to determine the elongation of the specimens. A gear-driven loading device applied constant extension rates to the specimens. The load was measured using a load cell that was external to the autoclave (see Figure 1). Extension was measured on a linear variable differential transformer (LVDT) between the autoclave and the loading rod.

Reduction of area was determined by measuring the dimensions of the specimen before the test and by measuring the fracture surface area after the test. The fracture surfaces were examined using optical and scanning electron microscopy to determine the mode(s) of failure.

The environment used in the SSR tests was the same as that used in corrosion tests. Inlet ground water flowed through crushed basalt in the bottom of the autoclave at about $40 \mathrm{ml} / \mathrm{h}$. Tests were also conducted in air at $250^{\circ} \mathrm{C}$ using the same test machine. 


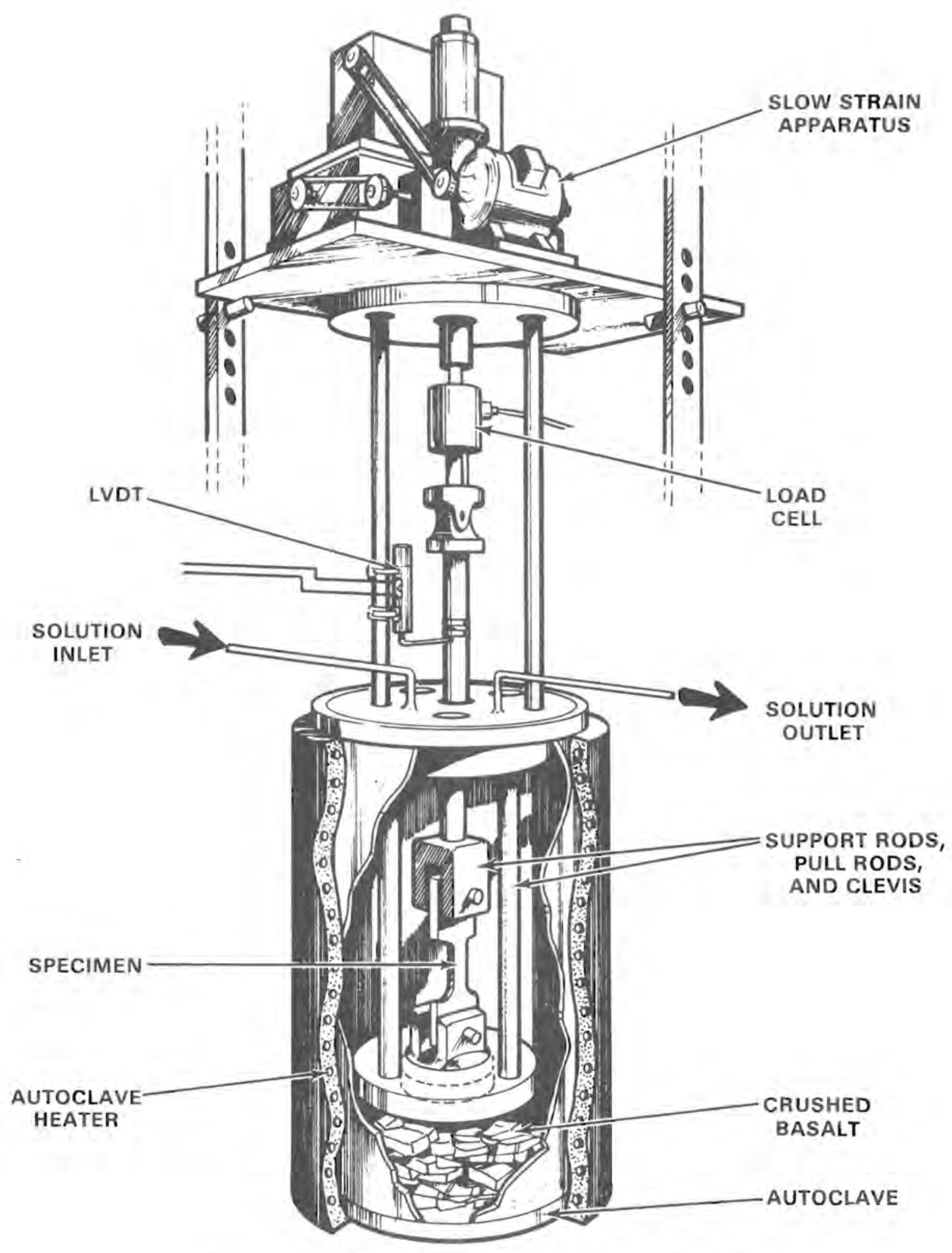

FIGURE 1. Slow Strain Rate Testing System 
FATIGUE CRACK GROWTH RATE TESTS

FCGR tests were performed in basalt ground water, fluoride-ion-enhanced basalt ground water, and high-purity water. The tests were done at $90^{\circ} \mathrm{C}$, using the environmental chamber shown in Figure 2. The flow rate was maintained at $\sim 100 \mathrm{ml} / \mathrm{h}$ using an in-line metering device. The inlet water chemistry was the same as that given in Table 1, except for the fluoride-ion-enhanced ground

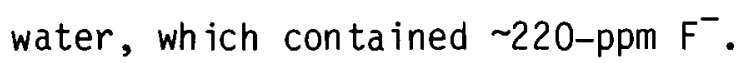

FCGR tests were done at cyclic frequencies of $5.0,1.0,0.1$, and $0.01 \mathrm{~Hz}$ so that effects of cyclic loading frequency on crack growth rate could be determined. A sinusoidal waveform with a loading ratio of $R=0.1^{(a)}$ was used for all tests.

The simulated ground water solution used in the FCGR tests was exposed to air before and during the tests. This exposure technically violates the "reference Hanford basalt ground water" storage condition (Rockwell Hanford Operations 1980) because oxygen fugacity was not controlled and $\mathrm{CO}_{2}$ was absorbed in the solution. However, the purpose of these preliminary FCGR tests was to investigate possible adverse effects of ground waters on titanium in a scoping sense and not necessarily to accurately simulate repository conditions.

\section{MATERIALS}

The materials used in this study (Ti-grade 2 and Ti-grade 12) are commercially available ASTM grades. Grade 2 is one of the commercial purity grades, specified by maximum allowable impurity content. Grade 12, which contains nominally $0.8 \% \mathrm{Ni}$ and $0.3 \% \mathrm{Mo}$, was developed for resistance to crevice corrosion and pitting in elevated temperature, high-chloride environments (Covington and Palmer 1974). The Ti-grade 2 sheet was $1.27 \mathrm{~mm}(0.050 \mathrm{in.})$ thick, and the Ti-grade 12 sheet was $0.79 \mathrm{~mm}(0.031 \mathrm{in.})$ thick. Compositions and room temperature mechanical properties are 1 isted in Tables 2 and 3 , respectively.

(a) The loading ratio is the ratio of minimum to maximum applied load. 


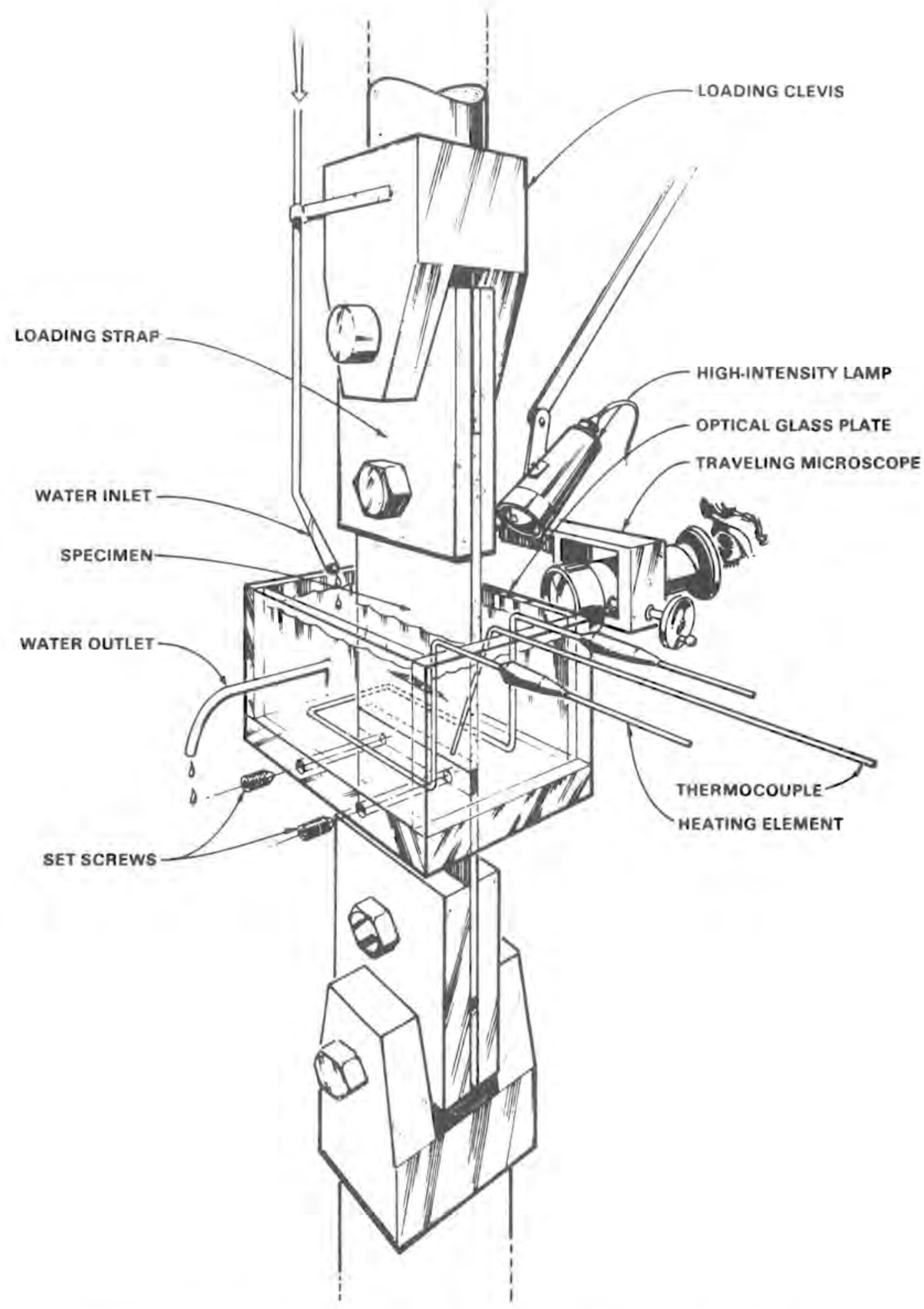

FIGURE 2. Fatigue Crack Growth Rate Testing System 
TABLE 2. Composition of Ti-Grade 2 and Ti-Grade 12 Used in This Study and ASTM Nominal Compositions

\begin{tabular}{|c|c|c|c|c|c|c|c|}
\hline \multirow{2}{*}{$\begin{array}{c}\text { ASTM Grade per } \\
\text { B-265-78 }\end{array}$} & \multicolumn{7}{|c|}{ Element, wt\% } \\
\hline & $\mathrm{N}$ & $C$ & $\mathrm{H}$ & 0 & $\mathrm{Fe}$ & Mo & $\mathrm{Ni}$ \\
\hline Grade 2 Actual & 0.009 & 0.011 & 0.005 & 0.12 & 0.12 & & \\
\hline $\begin{array}{l}\text { Grade } 2 \text { ASTM } \\
\text { Nominal (a) }\end{array}$ & 0.030 & 0.100 & 0.015 & 0.250 & 0.300 & & \\
\hline Grade 12 Actual & 0.008 & 0.021 & 0.005 & 0.13 & 0.12 & 0.30 & 0.67 \\
\hline $\begin{array}{l}\text { Grade } 12 \text { ASTM } \\
\text { Nominal }(a)\end{array}$ & 0.03 & 0.08 & 0.015 & 0.250 & 0.300 & 0.2 to 0.4 & 0.6 to 0.9 \\
\hline
\end{tabular}

(a) Maximum elemental levels except as noted, per ASTM B-265-78.

TABLE 3. Room Temperature Mechanical Properties of Ti-Grade 2 and Ti-Grade 12

\begin{tabular}{|c|c|c|c|}
\hline $\begin{array}{l}\text { Titan ium Grade } \\
\text { and Orientation }\end{array}$ & $\begin{array}{l}\text { Yield Strength, } \\
\mathrm{MPa} \text { (ksi) }\end{array}$ & $\begin{array}{l}\text { Tensile Strength, } \\
\mathrm{MPa} \text { (ksi) } \\
\end{array}$ & Elongation, $\%$ \\
\hline Grade $2 L^{(a)}$ & $351(51)$ & $497(74)$ & 29 \\
\hline Grade $2 T^{(b)}$ & $393(57)$ & $517(72)$ & 28 \\
\hline Grade-12 L & $427(62)$ & $600(87)$ & 22 \\
\hline Grade $12 \mathrm{~T}$ & $600(87)$ & $696(101)$ & 18 \\
\hline
\end{tabular}

(a) $L=$ longitudinal; loading stress is parallel to the rolling direction of the material.

(b) $\mathrm{T}=$ transverse; loading stress is perpendicular to the rolling direction of the material. 
$\underline{\text { RESULTS }}$

Statically loaded corrosion tests, SSR tests, and FCGR tests have been performed to determine the relative susceptibility of Ti-grade 2 and Ti-grade 12 to environmentally ass isted fracture. The results presented in this section represent a summary of the work completed to date.

\section{STATICALLY LOADED CORROSION TESTS}

Statically loaded U-bend and WOL corrosion specimens were used for scoping tests to evaluate the susceptibility of titanium to environmentally enhanced fracture. The titanium U-bend specimens exhibited no signs of pitting or cracking at $250^{\circ} \mathrm{C}$, and the weight change after cleaning was very low $\left(<2 \mathrm{mg} / \mathrm{dm}^{2}\right)$. Analysis of the water at the autoclave inlet and outlet indicated that dissolved oxygen was readily consumed by basalt at $250^{\circ} \mathrm{C}$. (An inlet oxygen concentration of $\sim 6 \mathrm{ppm}$ decreased to $\sim 0.3 \mathrm{ppm}$ at the outlet in an autoclave containing basalt chips but no metallic specimens.)

WOL specimens were exposed to oxic basalt ground water at $250^{\circ} \mathrm{C}$ for $3 \mathrm{mo}$. The stress intensity in the specimens $(\sim 50 \mathrm{ksi} \sqrt{\mathrm{in} .})$ was high enough to initiate tunneling $(a)$ fracture in the Ti-grade 12 specimens; this stable crack growth occurred as the specimens were loaded and before they were exposed to ground water. The compliance and wedge load were measured before and after the exposure. There was no indication that crack growth occurred as a result of the exposure, even at this relatively high stress intensity.

\section{SLOW STRAIN RATE TESTS}

SSR tests of Ti-grade 2 and $\mathrm{Ti}$-grade 12 were conducted in basalt ground water at $150^{\circ} \mathrm{C}, 250^{\circ} \mathrm{C}$, and $300^{\circ} \mathrm{C}$ and in air at $20^{\circ} \mathrm{C}$ and $250^{\circ} \mathrm{C}$. Ti-grade 2 was tested in the $\mathrm{LT}^{(\mathrm{a})}$ orientation, and Ti-grade 12 was tested in both the LT

(a) Tunneling is a type of crack growth common in low-strength titanium, where interior crack growth exceeds surface crack growth. In this case, crack growth occurred inside the specimen during loading in air but could not be observed at the surface. The wOL specimens were fatigue precracked to provide the most favorable conditions for crack extension. 
and $T L$ orientations. The grain texture of the two materials is similar al though the mechanical properties of Ti-grade 12 have been found to be more an isotropic.

In tests of $\mathrm{Ti}$-grade 2 and $\mathrm{Ti}$-grade 12 at $150^{\circ} \mathrm{C}$ and $300^{\circ} \mathrm{C}$, on $1 \mathrm{y}$ the end points (highest and lowest strain rates) were evaluated. This test design was chosen as the most effective way of determining strain rate effects from a 1 imited number of specimens, based on earlier observations that the maximum ductility decrease occurred at the lowest strain rates. The effects of temperature on ductility of Ti-grade 2 can best be seen by comparing results from the $150^{\circ} \mathrm{C}$ and $300^{\circ} \mathrm{C}$ tests (see Figure 3 ). The reduction of area is enhanced by testing at a higher temperature at the higher strain rates, but the opposite effect is found at the lower strain rate. Elongation is lower at $300^{\circ} \mathrm{C}$ than at $150^{\circ} \mathrm{C}$, especially in tests conducted at a low strain rate.

Results of the SSR tests of Ti-grade 2 in basalt ground water and in air at $250^{\circ} \mathrm{C}$ are presented in Figure 4 . In each case, ductility decreased with decreasing strain rate. The extent of the ductility decrease is about the same in each environment.

SSR test results of Ti-grade 2 are summarized in Figure 5 . At the higher strain rate, elongation increased at higher temperatures; at the lower strain rate, elongation decreased at higher temperatures. Reduction of area decreased with increasing temperature at both strain rates.

Ti-grade 12 (LT orientation) is less sensitive to strain rate and temperature effects (see Figure 6 ). Elongation is somewhat diminished by testing at $300^{\circ} \mathrm{C}$; however, reduction of area is unaffected. At $250^{\circ} \mathrm{C}$, both elongation and reduction of area decrease with decreasing strain rate (see figure 7). The magnitude of the decrease is about the same in basalt ground water as it is in air. A comparison of tests done at $20^{\circ} \mathrm{C}, 150^{\circ} \mathrm{C}, 250^{\circ} \mathrm{C}$, and $300^{\circ} \mathrm{C}$ at $10^{-4} / \mathrm{s}$ and $2 \times 10^{-7} / \mathrm{s}$ in air and basalt ground water is given in Figure 8 . Reduction of

(a) "LT" indicates that the specimen is loaded in the longitudinal (rolling) direction and the crack propagates in the transverse direction (perpendicular to the rolling direction). "TL" indicates that the specimen is loaded in the transverse direction and the crack propagates in the longitudinal direction. 


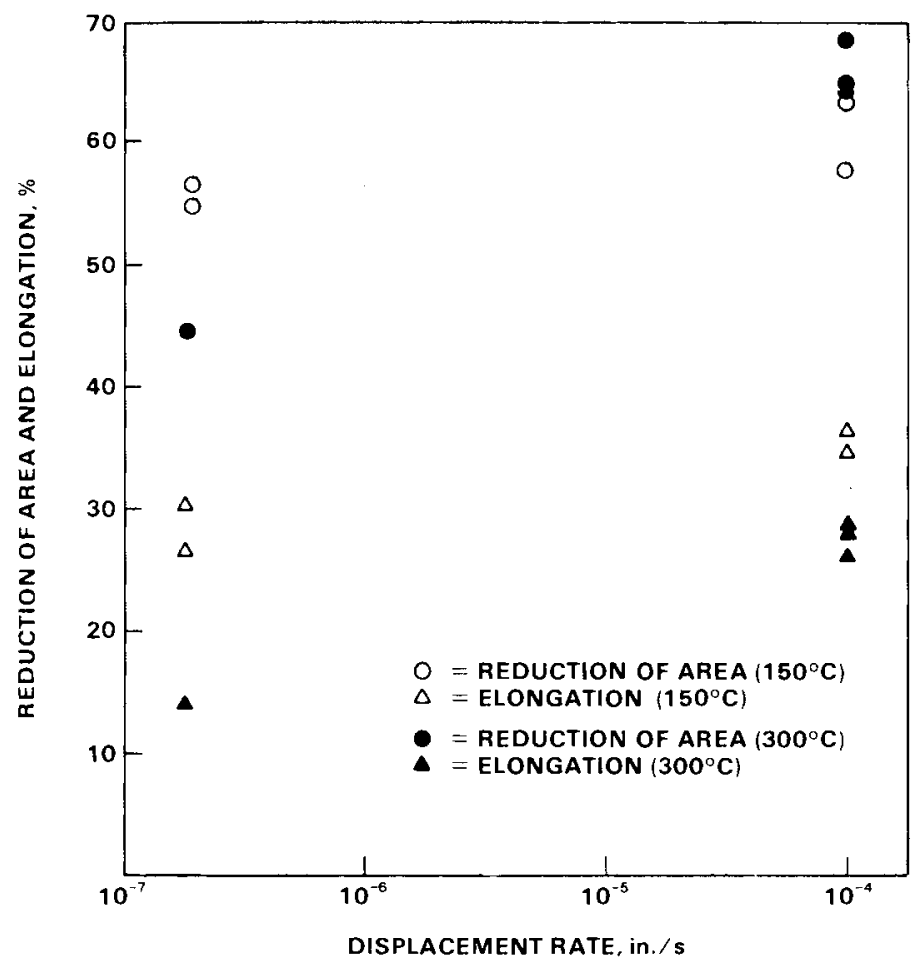

FIGURE 3. Reduction of Area and Elongation of Ti-Grade 2 (LT orientation) in Basalt Ground Water at $150^{\circ} \mathrm{C}$ and $300^{\circ} \mathrm{C}$

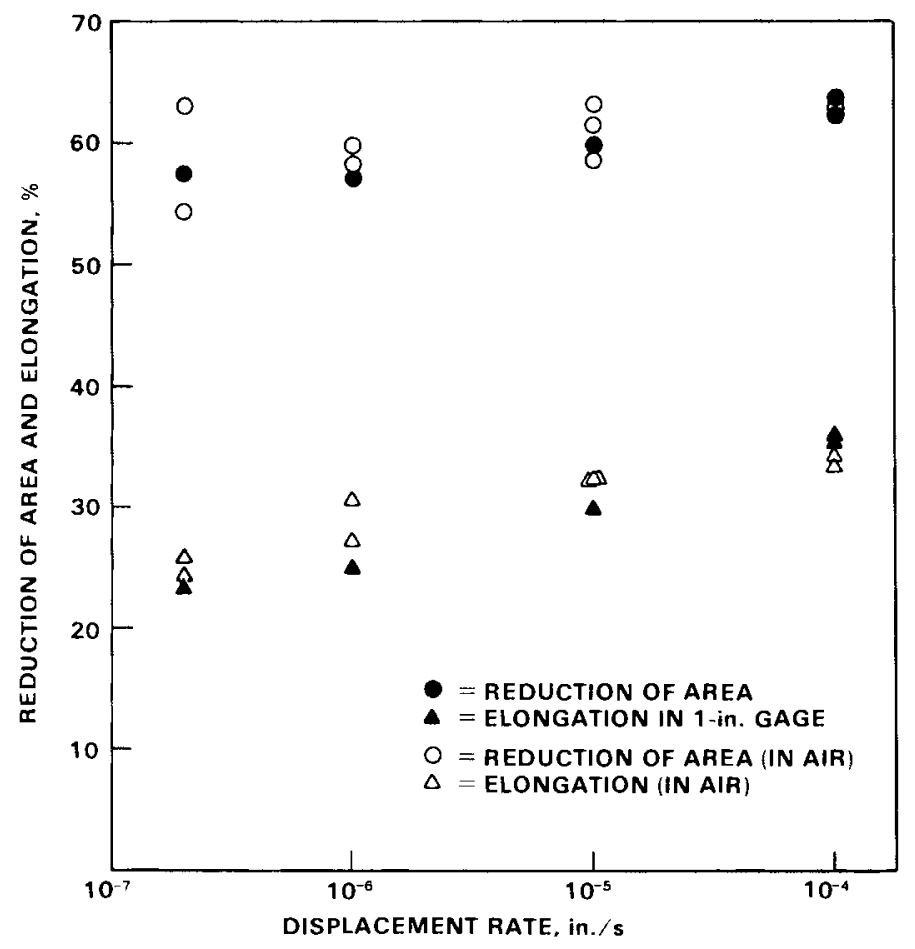

FIGURE 4. Reduction of Area and Elongation of Ti-Grade 2 (LT orientation) in Basalt Ground Water and Air at $250^{\circ} \mathrm{C}$ 


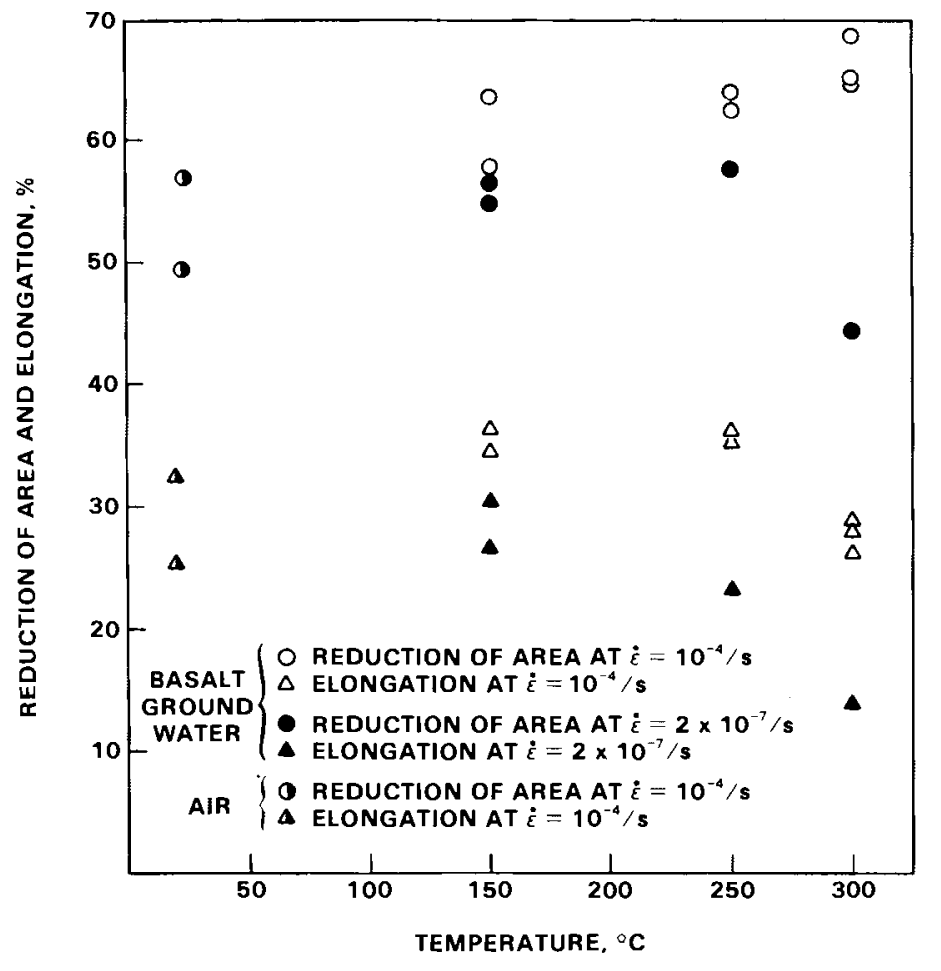

FIGURE 5. Reduction of Area and Elongation of Ti-Grade 2 (LT orientation) as a Function of Temperature

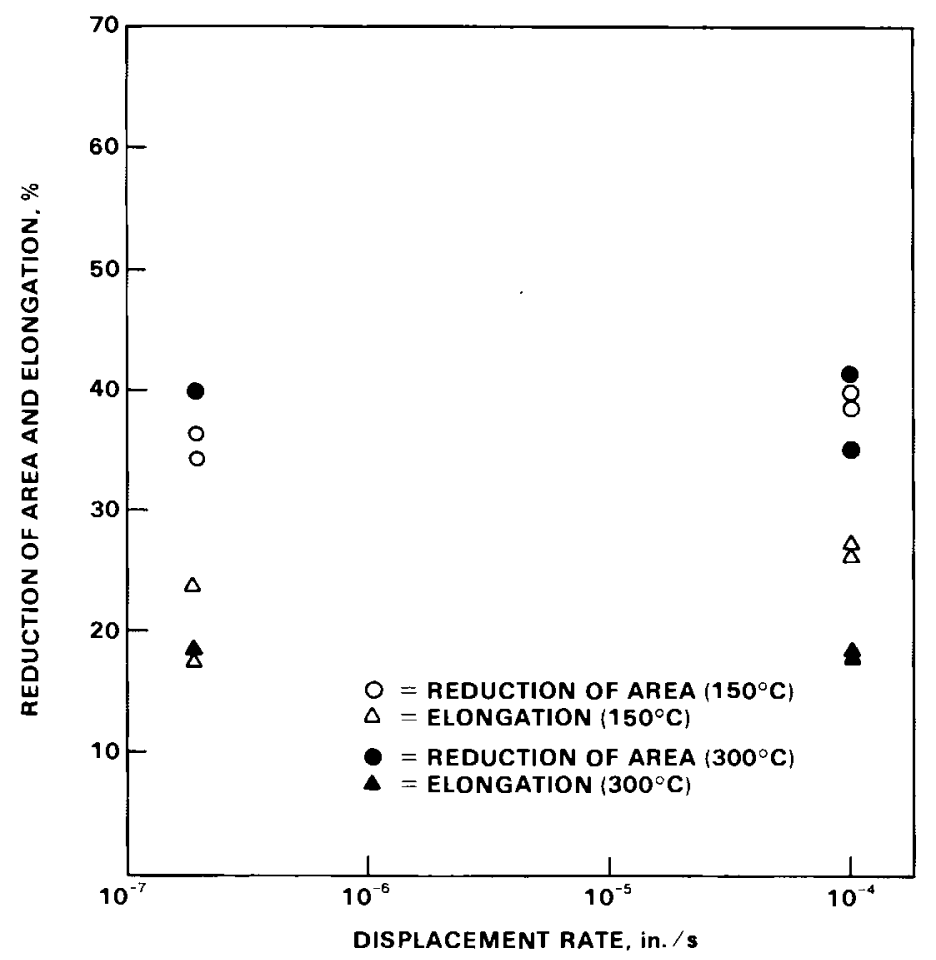

FIGURE 6. Reduction of Area and Elongation of Ti-Grade 12 (LT orientation) in Basalt Ground Water at $150^{\circ} \mathrm{C}$ and $300^{\circ} \mathrm{C}$ 


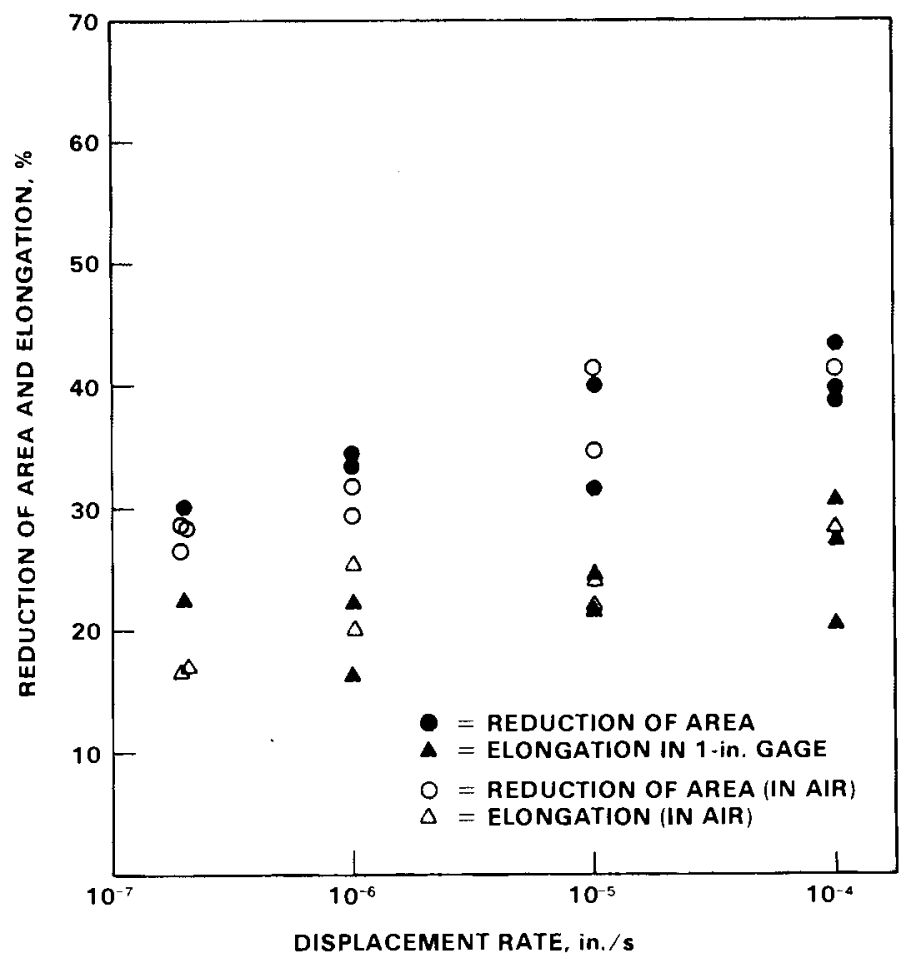

FIGURE 7. Reduction of Area and Elongation of Ti-Grade 12 (LT orientation) in Basalt Ground Water and Air at $250^{\circ} \mathrm{C}$

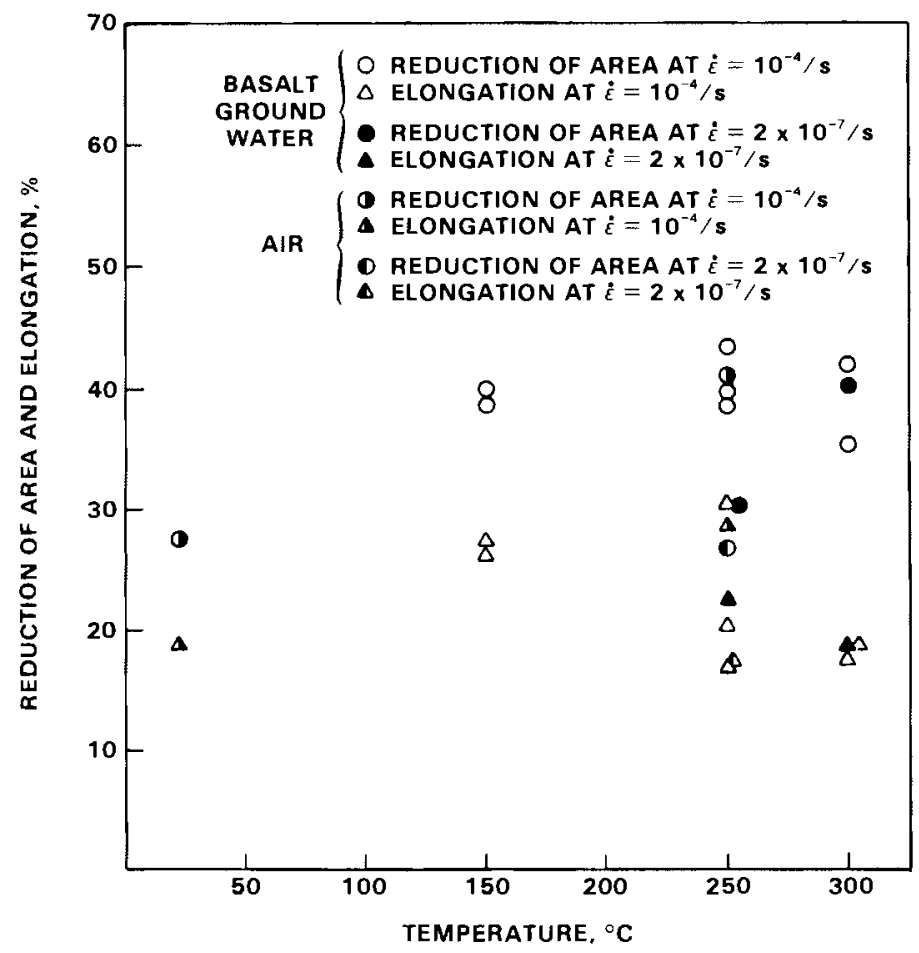

FIGURE 8. Reduction of Area and Elongation of Ti-Grade 12 (LT orientation) as a Function of Temperature 
area is sensitive to strain rate. At the higher strain rate, reduction of area increased with increasing temperature; but at the lower strain rate, reduction of area was lower at $250^{\circ} \mathrm{C}$ than at 150 or $300^{\circ} \mathrm{C}$. In other words, reduction of area reached an apparent minima at $\sim 250^{\circ} \mathrm{C}$.

The results of SSR testing of Ti-grade 12 (TL orientation) are similar to those of Ti-grade 12 (LT orientation). At $150^{\circ} \mathrm{C}$, the effect of strain rate on reduction of area was small (see Figure 9); and at $300^{\circ} \mathrm{C}$, reduction of area was strain rate sensitive, but elongation was only marginally affected. Elongation of $\mathrm{Ti}$-grade 12 in the TL orientation was lower than in the LT orientation regardless of the environment due to the smaller effective grain size and the as sociated higher strength. At $250^{\circ} \mathrm{C}$, Ti-grade 12 was severely affected by changes in strain rate; this effect is more pronounced in basalt ground water than in air (see Figure 10). A summary of data from the highest $\left(10^{-4} / \mathrm{s}\right.$ ) and lowest $\left(2 \times 10^{-7} / \mathrm{s}\right)$ SSR tests is presented in Figure 11 . The greatest susceptibility to strain rate effects was found at $250^{\circ} \mathrm{C}$. The ductility of Ti-grade 12

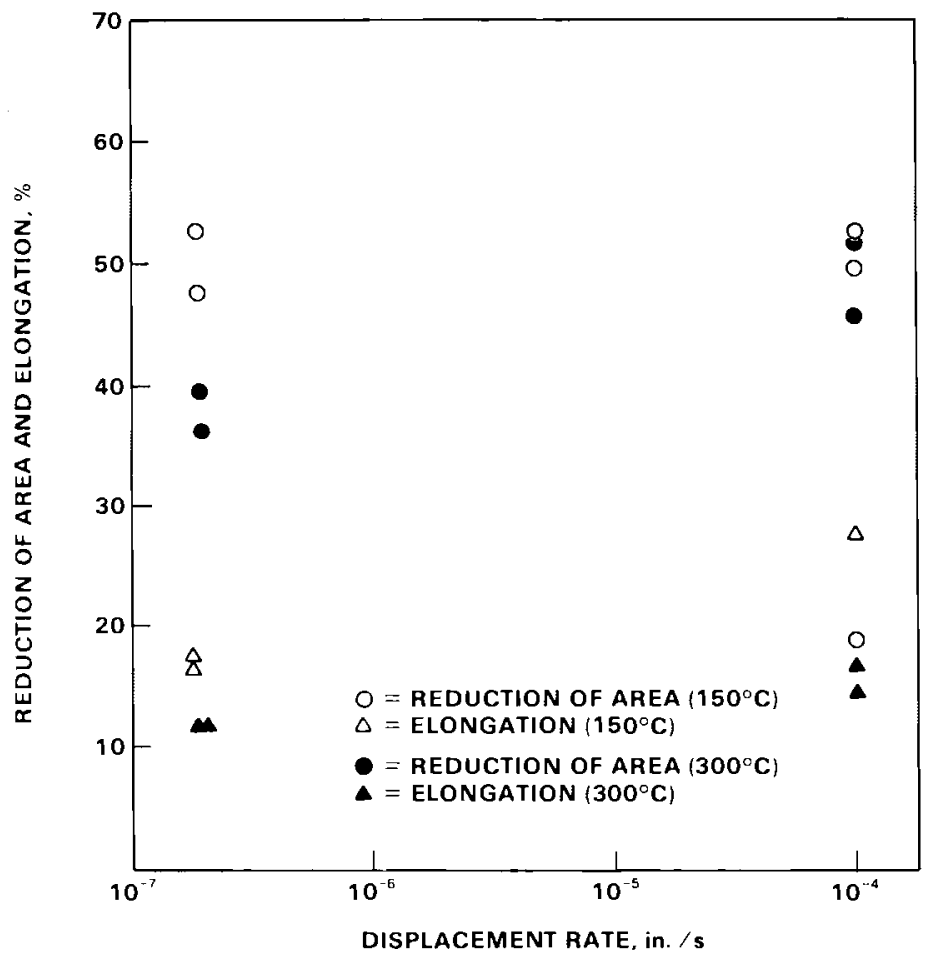

FIGURE 9. Reduction of Area and Elongation of Ti-Grade 12 (TL or ientation) in Basalt Ground Water at $150^{\circ} \mathrm{C}$ and $300^{\circ} \mathrm{C}$ 


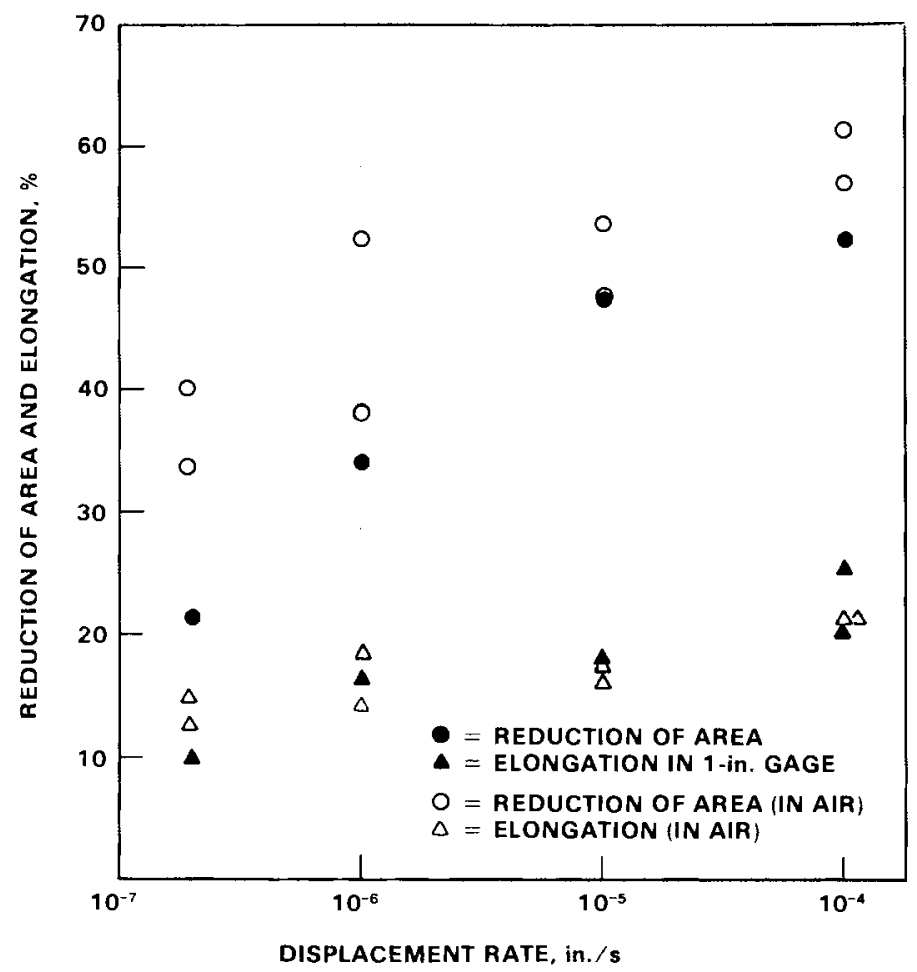

FIGURE 10. Reduction of Area and Elongation of Ti-Grade 12 (TL orientation) in Basalt Ground Water and Air at $250^{\circ} \mathrm{C}$

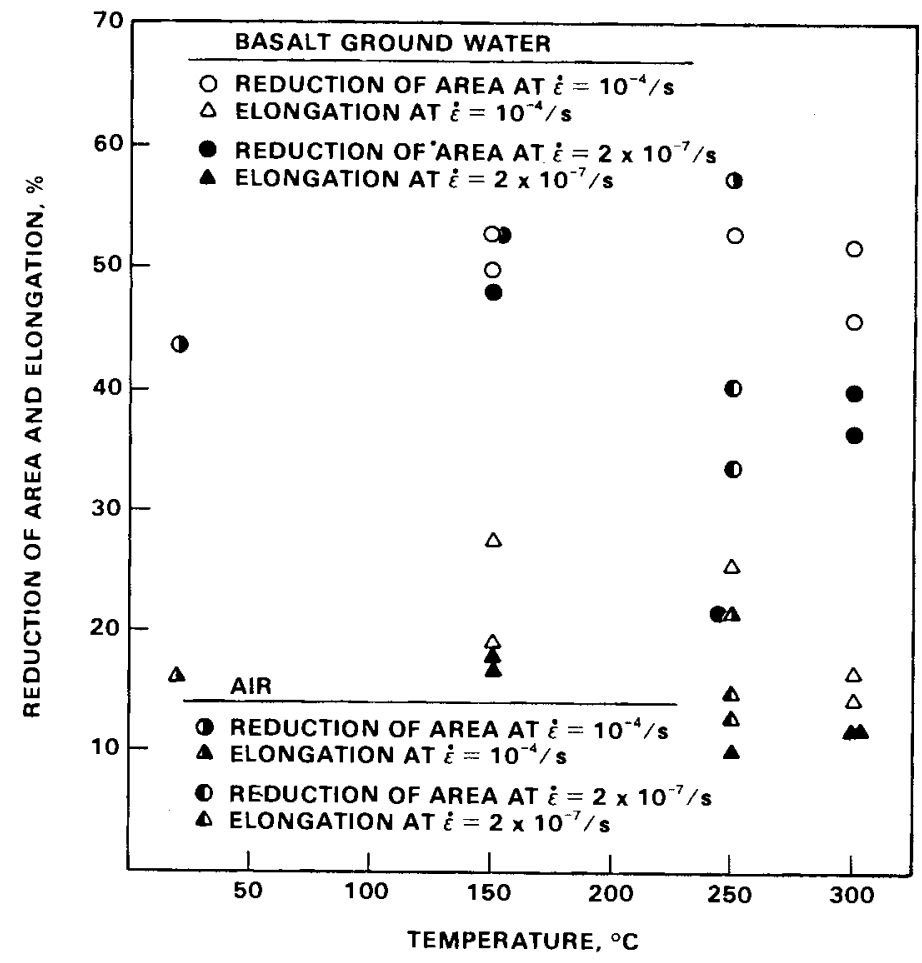

FIGURE 11. Reduction of Area and Elongation of Ti-Grade 12 (TL orientation) as a Function of Temperature 
( $T L$ orientation) was strongly influenced by the testing environment, and elongation was severely diminished at $250^{\circ} \mathrm{C}$ when the tests were conducted in basalt ground water. This effect was judged to be of sufficient importance to warrant further investigation. A study of the microstructure of the material and the fracture surfaces was conducted in an attempt to determine the causes of the ductility diminution.

A specimen that had exhibited low ductility and a piece of the as-received sheet were metallographically examined to determine whether or not the loss of ductility at low strain rates was caused by formation of hydrides. The specimen and the original material were polished and anodized to reveal a hydride phase. There was no concentration of hydrides near the fracture surface, and the distribution of hydride phase appeared to be the same in the fractured specimen as it was in the as-received sheet.

Fracture surfaces of specimens with high and low ductility in SSR tests were examined to determine the mode of fracture. Fracture surfaces of Ti-grade 2 specimens (LT orientation) are shown in Figure 12. The fracture occurred by microvoid coalescence in both cases, and there is no apparent difference between the fracture surfaces al though the strain rate was 500 times lower in Figure 12b than in Figure 12a. Similar results were obtained with Ti-grade 12 (not shown) where specimens of each strain rate and orientation were examined; no significant differences were found.

\section{FAT IGUE CRACK GROWTH RATE TESTS}

FCGR tes ts were conducted to determine the relative susceptibility of Ti-grade 2 and Ti-grade 12 to environmentally enhanced fracture in an environment similar to that expected in a basalt repository. In these tests, susceptibility to environmentally enhanced fracture is indicated by increased crack growth rate relative to an inert environment or by frequency-dependent FCGR.

No acceleration of crack growth rate was found in a repositoryrepresentative environment relative to an innocuous environment as is shown in Figures 13 and 14. The crack growth rate of Ti-grade 12 (LT and TL orientations) in flouride-ion-enhanced basalt ground water was compared with the 


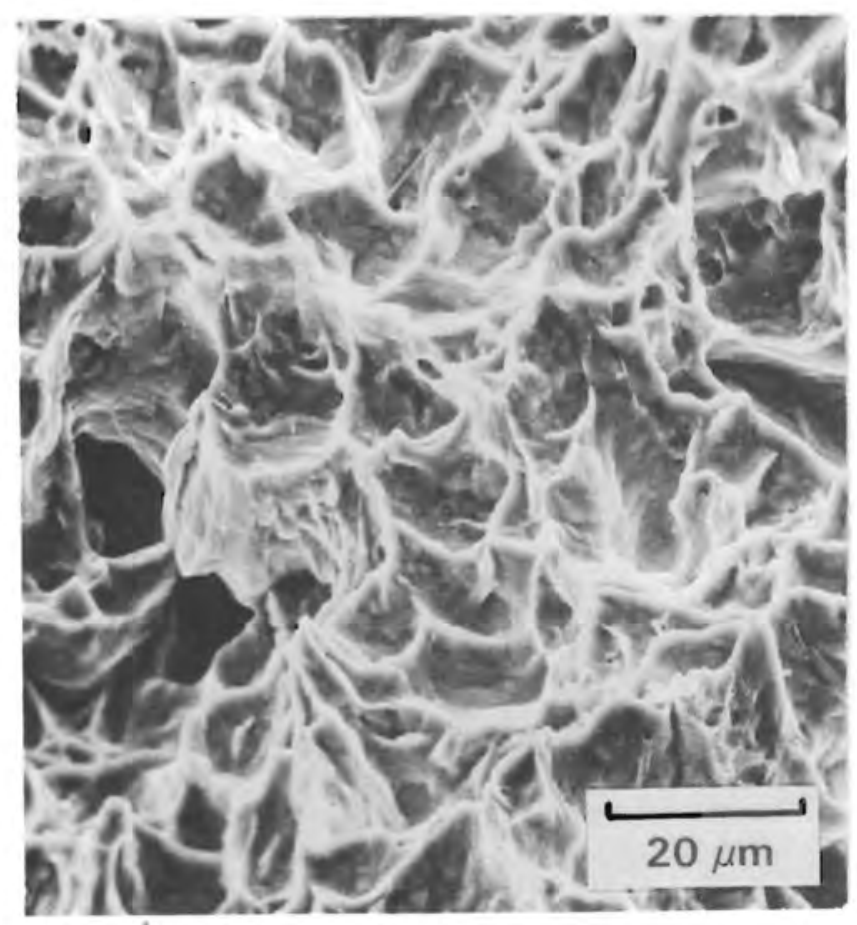

(a) $10^{-4} / \mathrm{s}$ Strain Rate

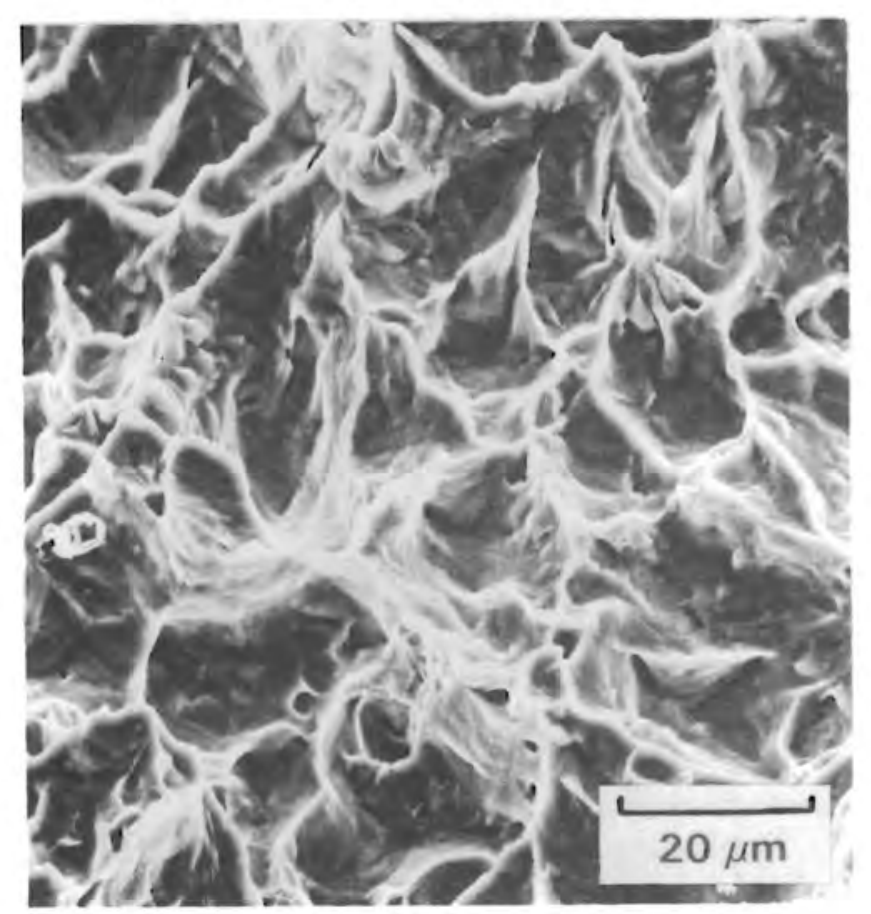

(b) $2 \times 10^{-7} / \mathrm{s}$ Strain Rate

FIGURE 12. Fracture Surfaces of Ti-Grade 2 Specimens (LT orientation) Strained to Failure in Basalt Ground Water at $250^{\circ} \mathrm{C}$ 


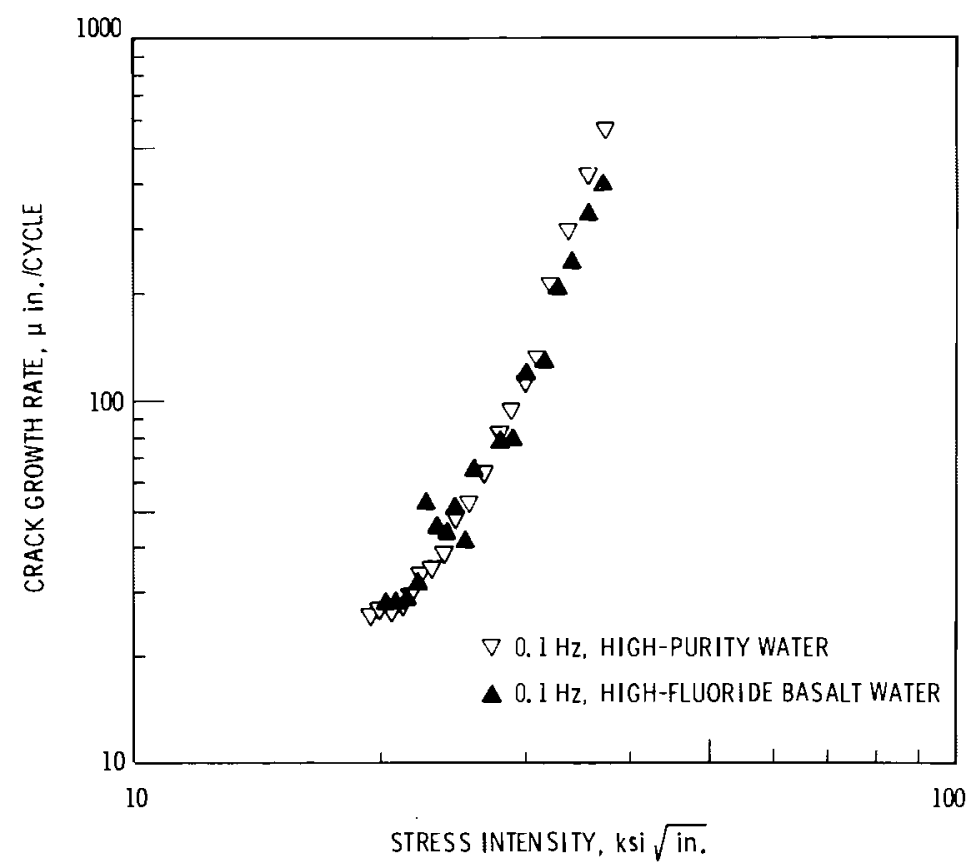

FIGURE 13. Fatigue Crack Growth Rate of Ti-Grade 12 (LT orientation) Tested at $0.1 \mathrm{~Hz}$ in Fluoride-Ion-Erihanced Basalt Ground water and High-Purity water at $90^{\circ} \mathrm{C}$

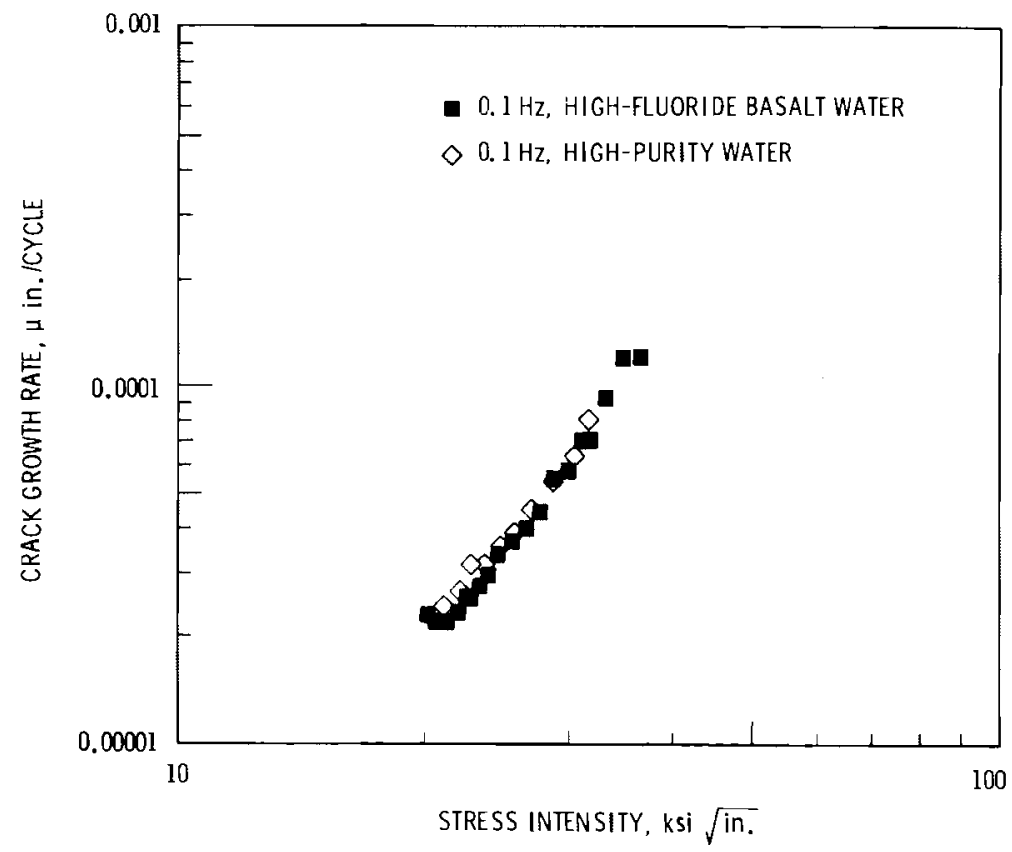

FIGURE 14. Fatigue Crack Growth Rate of Ti-Grade 12 ( $T L$ orientation) Tested at $0.1 \mathrm{~Hz}$ in Fluoride-Ion-Enhanced Basalt Ground Ground Water and High-Purity Water at $90^{\circ} \mathrm{C}$ 
crack growth rate in high-purity water. The fluoride-ion-enhanced ground water was used for this comparison because it is more likely to be aggressive in causing environmentally enhanced fracture due to the ability of fluoride ions to break down the passivating film.

Results of the investigation of the potential effects of frequency and fluoride-ion additions to the simulated ground water on FCGR are illustrated in Figures 15 and 16. In Figure 15, the FCGR of Ti-grade 2 (TL or ientation) was found to be unaffected by the presence of high fluoride-ion content or the frequency of cyclic loading. A similar result was found for Ti-grade 12 (LT orientation); see Figure 16. Although both the decreased frequency and the increased fluoride-ion content are considered possible accelerating factors, the FCGR did not increase. 


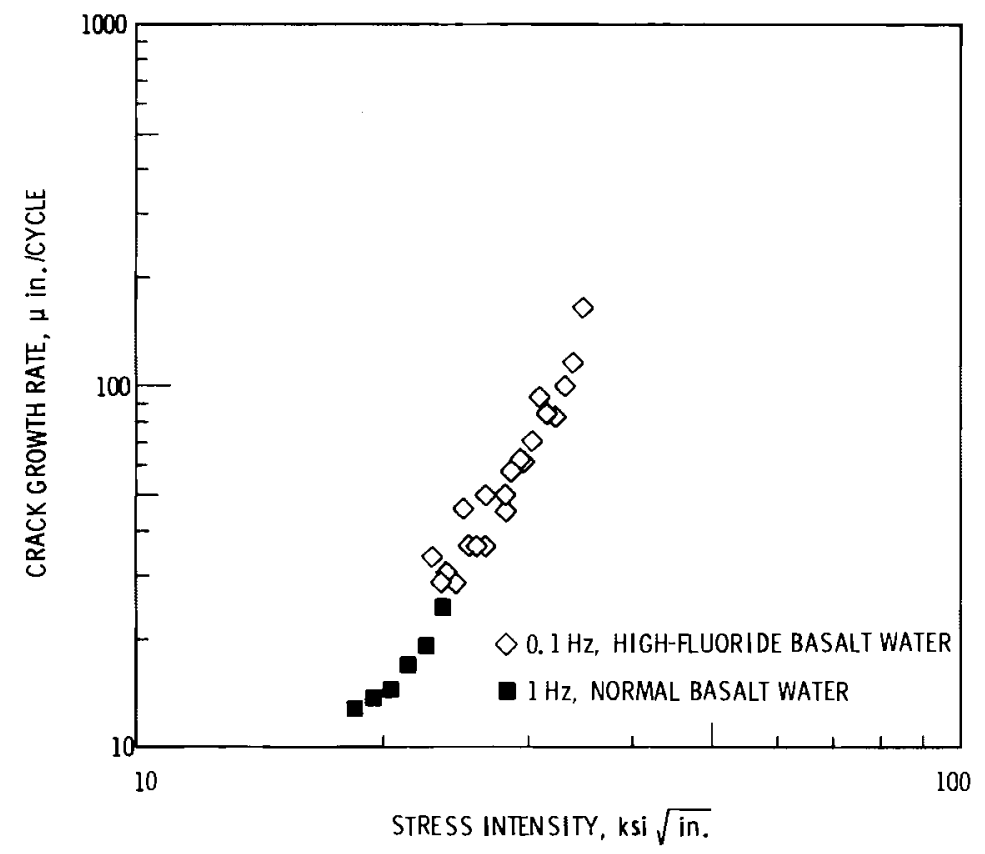

FIGURE 15. Fatigue Crack Growth Rate of Ti-Grade 2 (TL orientation) Tes ted at $1 \mathrm{~Hz}$ in Basalt Ground Water and at $0.1 \mathrm{~Hz}$ in Fluoride-Ion-Enhanced Ground Water at $90^{\circ} \mathrm{C}$

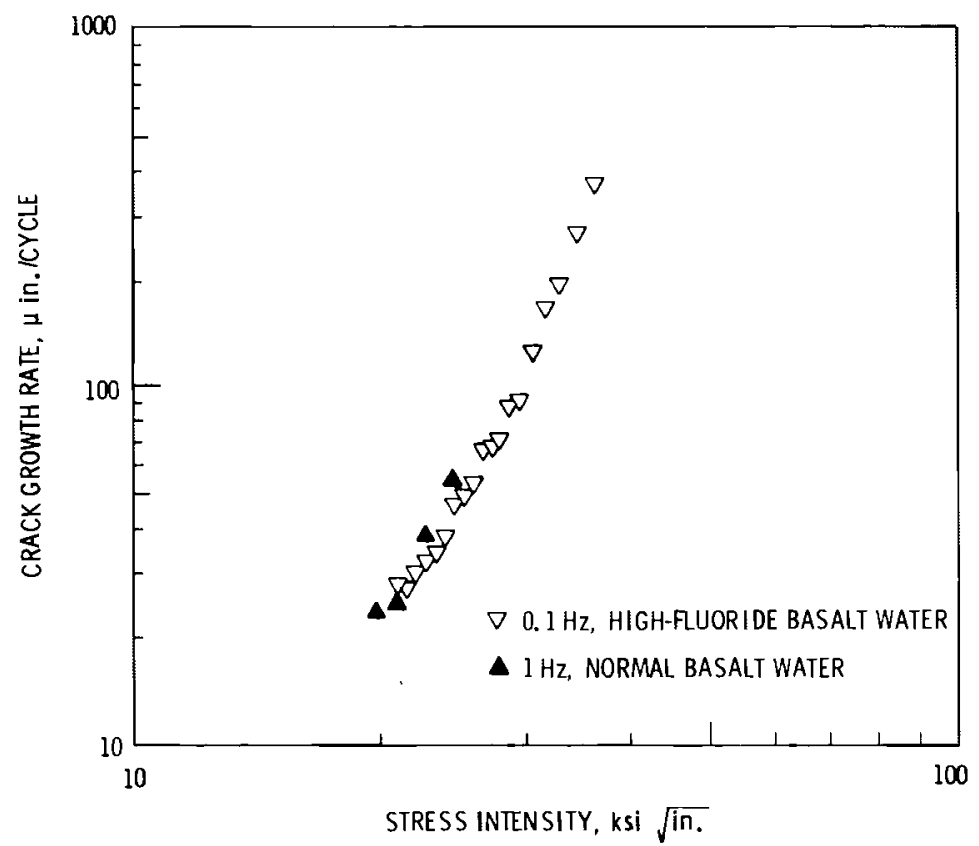

FIGURE 16. Fatigue Crack Growth Rate of Ti-Grade 12 (LT orientation) Tested at $1 \mathrm{~Hz}$ in Basalt Ground Water and at $0.1 \mathrm{~Hz}$ in Fluoride-I on-Enh anced Ground Water at $90^{\circ} \mathrm{C}$ 


\section{DISCUSSION}

In statically stressed corros ion tests, low corrosion rates of Ti-grade 2 and Ti-grade 12 were obtained and no localized corrosion was observed. These results contrast to results obtained in an oxic brine environment at $150^{\circ} \mathrm{C}$ (Slate et al. 1982), where the Ti-grade 2 was severely pitted and the weight changes were greater. The fact that Ti-grade 2 was pitted at $150^{\circ} \mathrm{C}$ in brine but was not pitted at $250^{\circ} \mathrm{C}$ in basalt ground water indicates that the basalt ground water is a less aggressive environment and that Ti-grade 2 is susceptible to pitting under certain conditions. The low oxygen fugacity of the basalt ground water in contact with the specimens and the relatively higher concentration of halide and sulfate ions in the brine may account for the difference.

Both Ti-grade 2 and Ti-grade 12 exhibited strain rate dependency in SSR tests at particular combinations of temperature and strain rate. This dependency was characterized by a loss of ductility at lower strain rates. Ti-grade 2 was most susceptible to strain rate effects at $300^{\circ} \mathrm{C}$ (over the range of temperatures studied), and Ti-grade 12 was most susceptible at $250^{\circ} \mathrm{C}$.

The most severe strain rate effect--in Ti-grade 12 (TL orientation) at $250^{\circ} \mathrm{C}$-was enhanced by the basalt ground water environment; however, the effect cannot be attributed entirely to the presence of the environment. Examination of specimens fractured at $10^{-4}, 10^{-5}, 10^{-6}$, and $2 \times 10^{-7} / \mathrm{s}$ in basalt ground water and in air revealed no signs of any fracture mode other than microvoid coalescence. This result indicates that the mechan ism of ductility diminution was not SCC because it would have caused a fracture surface with a faceted or granular appearance. The ductility diminution cannot be attributed to hydriding because there was no evidence of environmentally enhanced or strain-enhanced hydride formation.

The effects of strain rate on reduction of area and elongation are shown clearly in Figures 17 and 18, where the difference between ductility measurements at the highest and lowest strain rates is plotted as a function of temperature for Ti-grade 2 and Ti-grade 12. This difference is highest in Ti-grade 2 at $300^{\circ} \mathrm{C}$ and in Ti-grade 12 at $250^{\circ} \mathrm{C}$. The effect is clearly less 


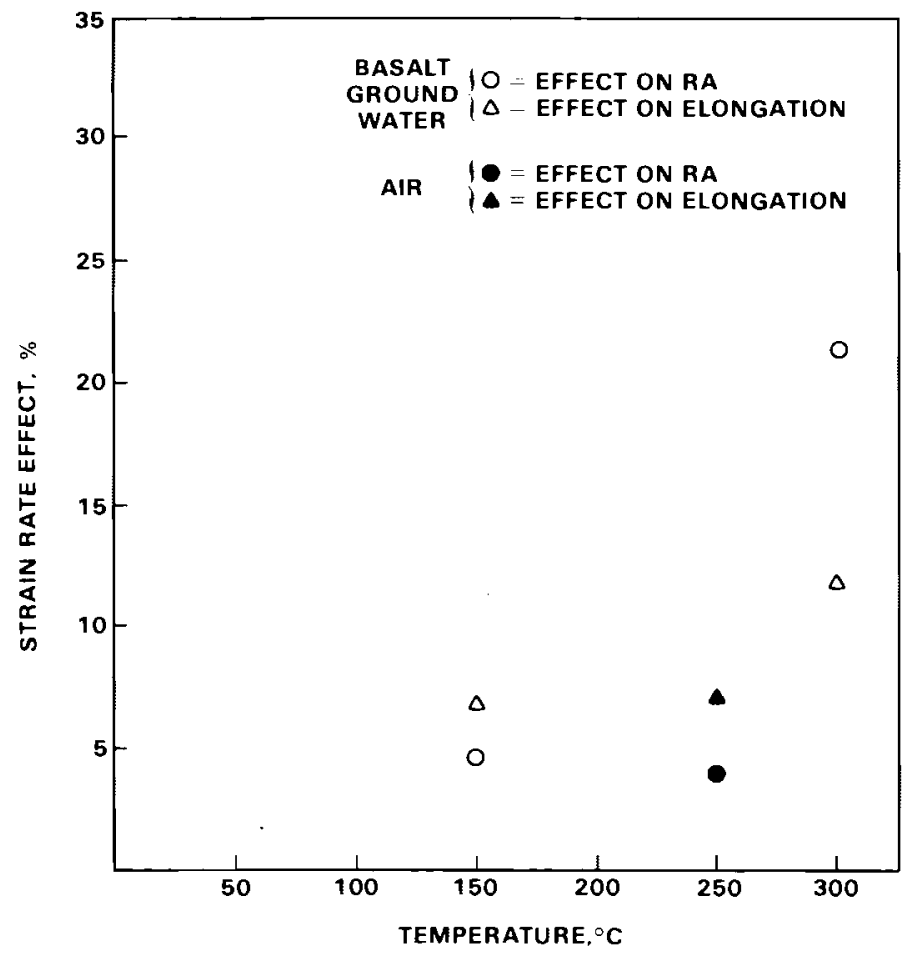

FIGURE 17. Summary of Strain Rate Effects in Ti-Grade 2 (LT orientation)

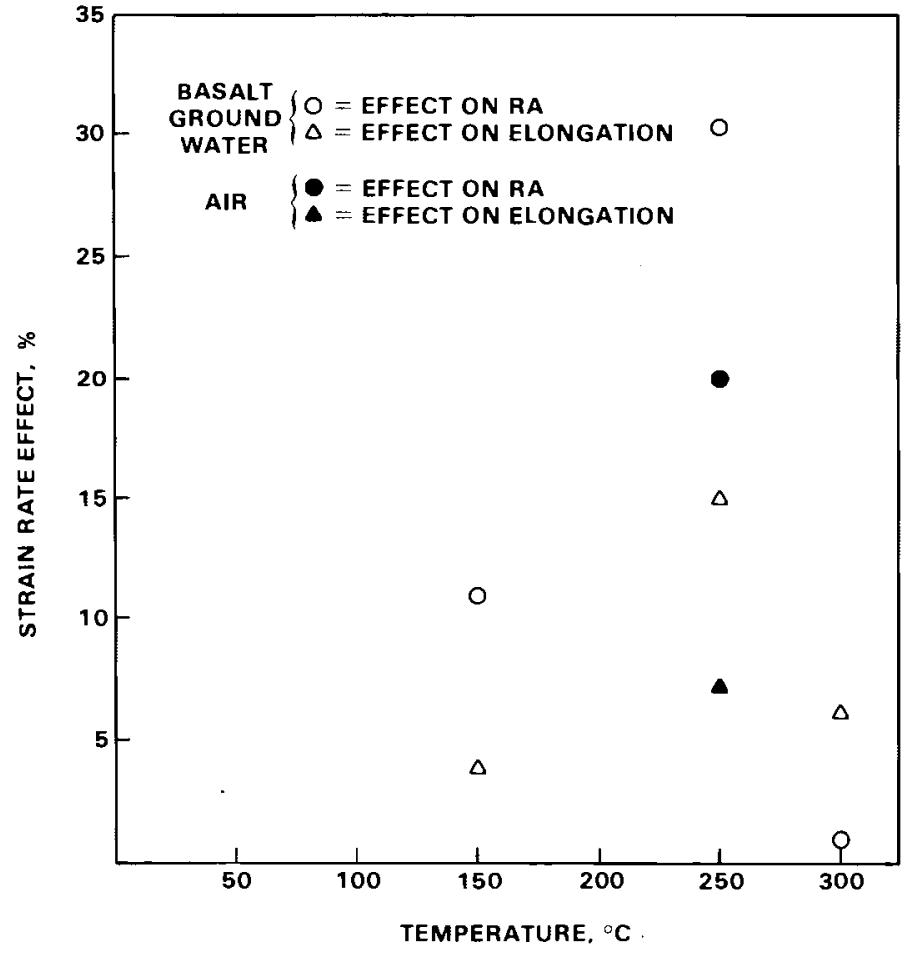

FIGURE 18. Summary of Strain Rate Effects in Ti-Grade 12 (TL orientation) 
pronounced in air, indicating that the strain rate effects are partly due to an interaction with the testing environment but that another (nonenvironmental) mechanism must be active.

Analysis of the available data suggests that the ductility decrease may be due to an internal strengthening mechanism. Research by Okazaki and Conrad (1973) indicates that the rate-controlling mechanism during the low-temperature $(T<0.3 \mathrm{Tm})$ plastic deformation of titanium is the overcoming of interstitial solute atoms by dislocations. Both static and dynamic strain aging have been observed in a titanium by various researchers. Static strain aging was observed in titanium after heating from 200 to $400^{\circ} \mathrm{C}$ at strain rates of $2.7 \times 10^{-5} / \mathrm{s}$ to $2.7 \times 10^{-3} / \mathrm{s}$ (Rosi and Perkins 1953). Dynamic strain aging was found to reach a maximum at $\sim 430$ to $530^{\circ} \mathrm{C}$; the temperature at which the maximum was found decreased with decreasing strain rate. The maximum strain aging found in this study occurred at $300^{\circ} \mathrm{C}$ in Ti-grade 2 and at $250^{\circ} \mathrm{C}$ in Ti-grade 12 . These temperatures correspond more closely with those associated with static strain aging, but the lowest strain rate used in the current study $\left(2 \times 10^{-7} / \mathrm{s}\right)$ is two orders of magnitude lower than the lowest strain rate used by Santhanam and Reed-Hi11 (1971).

Dynamic strain aging is normally associated with serrations in the loaddisplacement curve; however, in commercial-purity titanium, these serrations may be difficult to detect (Donor and Conrad 1973). In the current investigation, load was measured outside the autoclaves, and seal friction caused variations in the load-displacement curves. It was difficult to accurately measure load on the specimens, and small load variations resulting from discontinuous yielding could not be resolved.

Dynamic strain aging is associated with the interaction of interstitial solute atoms with dislocations. The exact mech anism has not yet been proven although two predominant theories exist. In one proposed mechanism, dislocations are pinned by impurities and more dislocations are generated to maintain the imposed strain rate. In another proposed mechanism, dynamic strain aging results from the drag of impurity atmospheres. In either case, diffusion of impurities, which is temperature dependent, must be sufficient to allow solute atoms to interact with dislocations at the imposed strain rate. 
It appears reasonable to attribute most of the ductility decrease found in Ti-grade 2 and Ti-grade 12 to strain aging occurring during the test; however, some environmental effects were also found (see Figures 17 and 18). It is possible that these effects may be caused by impurities introduced to the metal by breakdown of the passivating film and subsequent strain-assisted diffusion.

In FCGR tests of Ti-grade 2 and Ti-grade 12, the FCGR was found to be independent of testing environment ( $f$ luoride-ion-enhanced basalt ground water or high-purity water) and frequency (from 0.1 to $5.0 \mathrm{~Hz}$ ). This independence indicates that no mechan ism of environmentally enh anced cracking is operative at $90^{\circ} \mathrm{C}$. 


\section{REFERENCES}

Covington, L. C., and H. R. Palmer. 1974. A New Corros ion-Res istant Titanium Alloy Ti-38A for High Temperature Service. Henderson Technical Laborator ies, Timet Co., West Caldwe 11, North Dakota.

Donor, M., and H. Conrad. December 1973. "Deformation Mechan isms in Commercial $\mathrm{Ti}-50 \mathrm{~A}$ ( 0.5 at. pct. Oeg.) at Intermediate and High Temperatures (0.3-0.6 Tm)." Met. Trans. 4:2809.

Okazaki, K., and H. Conrad. August 1973. "Effects of Interstitial Content and Grain Size on the Strength of Titanium at Low Temperatures." Acta Meta 1lurgica 21:1117-1129.

Payer, J. H., W. E. Berry, and W. K. Boyd. 1976. "Constant Strain Rate Technique for Assessing Stress-Corrosion Susceptibility." Stress Corrosion-New Approaches, ASTM STP 610, American Society for Testing and Materials, pp. 82-93.

Pitman, S. G. October 1981. Investigation of Susceptibility of TitaniumGrade 2 and Titanium-Grade 12 to Environmental Cracking in a Simulated Basalt Repository Environment. PNL-3915, Pacific Northwest Laboratory, Richland, Washington.

Rockwel1 Hanford Operations. 1980. Engineering Order, RSD-BWI-DP-007, Jul y 11, 1980.

Rosi, F. D., and F. C. Perkins. 1953. ASM Trans. 45:972.

Santh anam, A. T., and R. E. Reed-Hi11. 1971. Met. Trans. 2:2619.

Slate, S. C., et a1. 1982. Feasibility of Using a High-Level Waste Canister as an Engineered Barrier in Disposal. PNL-4266, Pacific Northwest Laboratory, Richland, washington.

Westerman, R. E. October 1980. Investigation of Metallic, Ceramic, and Pol ymeric Materials for Engineered Barrier Applications in Nuclear-Waste Packages. PNL-3484, Pacific Northwest Laboratory, Richland, Washington.

Westerman, R. E., S. G. Pitman, and J. L. Nelson. 1982. Evaluation of Candidate Structural Barrier Materials for Containment of Nuclear Waste in Basalt and Tuff Repos itories-Progress Report. PNL-4364, Pacific Northwest Laboratory, Richland, washington. 


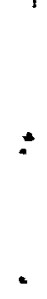




\section{DISTRIBUTION}

No. of

Copies

OFFSITE

G. Oertel

DOE Office of Nuclear Was te

Management

$N E-320$, GTN

Germantown, MD 20545

F. E. Coffman

DOE Office of Terminal Waste

Disposal and Remedial Action washington, DC 20545

A. F. Perge

DOE Office of Terminal Waste Disposal and Remedial Action Wash ington, DC 20545

R. D. Wal ton

DOE Division of Waste Products

MSB-107

P. 0. Box A

Aiken, SC 29801

W. W. Ballard

Doe Division of Waste Repository Dep loyment

Wash ington, DC 20545

C. R. Cooley

DOE Division of Waste Repository Deployment

wash ington, DC 20545

T. Longo

DOE Division of Waste Repository Deployment

Washington, DC 20545

2 R. Y. Lowrey

DOE Albuquerque Operations Office

Albuquerque, NM 87115
No. of

Copies

S. A. Mann

DOE Chicago Operations and Regional Office

Argonne, IL 60439

J. 0. Neff, Program Manager DOE Columbus Program Office 505 King Avenue

Columbus, $\mathrm{OH} 43201$

J. B. Whitsett

DOE Idaho Operations office 550 2nd Street

Idaho Falls, ID 83401

27 DOE Technical Information Center

Allied Chemical Corporation

File Copy

505 2nd St.

Idaho Falls, ID 83401

Argonne National Laboratory

Reference Library

9800 S. Cass Avenue

Argonne, IL 60439

M. Seitz

Argonne National Laboratory 9700 S. Cass Avenue

Argonne, IL 60439

M. J. Ste indler

Chemical Engineering Div.

Argonne National Laboratory

9700 S. Cass Avenue

Argonne, IL 60439

J. Holloway

Dept. of Chemistry

Arizona State University

Tempe, AZ 85281 
No. of

Copies

R. G. Post

College of Engineering

University of Arizona

Tucson, AZ 85721

A. Brecher

Arthur D. Little, Inc.

Acorn Park

Cambridge, MA 02104

W. Carbiener

Office of NWTS Integration

Battel le Memorial Institute

505 King Avenue

Col umbus, $\mathrm{OH} 43201$

J. 0 . Duguid

Office of NWTS Integration

Battel le Memorial Institute

505 King Avenue

Columbus, $\mathrm{OH} 43201$

R. J. Hall

Office of NWTS Integration

Battelle Memorial Institute

505 King Avenue

Columbus, $\mathrm{OH} 43201$

P. Hoffman

Office of NWTS Integration

Battelle Memorial Institute

505 King Avenue

Columbus, $\mathrm{OH} 43201$

S. J. Basham

Office of Nuclear Waste I solation

Battel le Memorial Institute

505 King Avenue

Columbus, $\mathrm{OH} 43201$

A. $B r$ ands tetter

Office of Nuclear Waste I solation

Battelle Memorial Institute

505 King Avenue

Columbus, $\mathrm{OH} 43201$
No. of

Copies

J. A. Carr

Office of Nuclear Waste Isolation

Battel le Memorial Institute 505 King Avenue

Columbus , $\mathrm{OH} 43201$

R. W. Cote

Office of Nuclear Waste Isolation

Battelle Memorial Institute

505 King Avenue

Columbus, $\mathrm{OH} 43201$

W. M. Hewitt

Office of Nuclear Waste Isolation

Battelle Memorial Institute 505 King Avenue

Columbus, $\mathrm{OH} 43201$

N. Hubbard

Office of Nuclear Waste Isolation

Battelle Memorial Institute 505 King Avenue

Columbus , $\mathrm{OH} 43201$

J. F. Kircher

Office of Nuclear waste Isolation

Battelle Memorial Institute 505 King Avenue

Columbus, $\mathrm{OH} 43201$

D. T. Moak

Office of Nuclear Waste Isolation

Battelle Memorial Institute 505 King Avenue

Columbus, $\mathrm{OH} 43201$

J. Moody

Office of Nuclear Waste Isolation

Battelle Memorial Institute 505 King Avenue

Columbus, $\mathrm{OH} 43201$ 
No. of

$\underline{\text { Copies }}$

W. M. Pardue

Office of Nuclear Waste I solation

Battel le Memorial Institute

505 King Avenue

Columbus, $\mathrm{OH} 43201$

G. E. Raines

Office of Nuclear Was te Isolation

Battel le Memorial Institute

505 King Avenue

Columbus, $\mathrm{OH} 43201$

10 B. Rawles

Office of Nuclear Waste Isolation

Battelle Memorial Institute

505 King Avenue

Columbus, $\mathrm{OH} 43201$

R. A. Robinson

Office of Nuclear Waste Isolation

Battelle Memorial Institute

505 King Avenue

Columbus, $\mathrm{OH} 43201$

J. W. Voss

Office of Nuclear Waste Isolation

Battelle Memorial Institute

505 King Avenue

Columbus, $\mathrm{OH} 43201$

Brookhaven National Laboratory

Reference Section

Information Division

Upton, NY 11973

T. M. Ahn

Brookhaven National Laboratory Upton, NY 11973

P. Colombo

Brookhaven National Laboratory

Upton, NY 11973
No. of

Copies

T. H. Pigford

University of California

Berkeley, CA 94720

I. A. Kilinic

Dept. of Geology

University of Cincinnati

Cincinnati, $\mathrm{OH} 45221$

W. L. Lindsay

Colorado State University

Fort Collins, CO 80523

R. F. Williams

Electric Power Research Institute

P.0. Box 10412

Palo Alto, CA 94301

Environmental Protection Agency

Technology Assessment Div is ion (AW-559)

Office of Radiation Programs

Wash ington, DC 20460

D. A. Knecht

Exxon Nuclear Idaho Corp.

P.0. Box 2800

Idaho Falls, ID 83401

L. L. Hench

Dept. of Materials Science and Engineering

University of Florida

Gainesville, FL 32611

J. P. Murray

Pierce Hall

Harvard University

Cambridge, MA 02138

R. E. Wilems

INTERA Env ir onmental Consultants, Inc.

11999 Caty Freeway, Ste. 610 Houston, TX 77079 
No. of

Copies

Lawrence Berkeley Laboratory Reference Library University of California Berkeley, CA 94720

R. Silva

Lawrence Berkeley Laboratory University of California

1 Cyclotron Rd.

Bldg. 70A/ 1160

Berkeley, CA 94720

Lawrence Livermore National Laboratory

Reference Library

P.0. Box 808

Livermore, CA 94550

F. Bazan

Lawrence Livermore National Laboratory

P.0. Box 808

Livermore, CA 94550

D. I sherwood

Lawrence Livermore National Laboratory

P. 0. Box 808

Livermore, CA 94550

R. D. McCright

Lawrence Livermore National Laboratory

P. 0. Box 808

Livermore, CA 94550

L. D. Ramspott

Lawrence Livermore National Laboratory

P.0. Box 808

Livermore, CA 94550

A. J. Rothman

Lawrence Livermore National Laboratory

P.0. Box 808

Livermore, CA 94550
No. of

Copies

T. J. Wolery

Lawrence Livermore National Labor atory

P.0. Box 808

Livermore, CA 94550

Los Alamos Scientific Laboratory Reference Library

P.0. Box 1663

Los Alamos, NM 87544

B. R. Erdal

Los Alamos Scientific Laboratory

CNC-11, MS-514

Los Alamos, NM 87545

A. Gancarz

Los Alamos Scientific Laboratory

CNC-11, MS-514

Los Alamos, NM 87545

J. Pomeroy

National Academy of Sciences

Comm. of Radioactive Waste

Management

National Research Council 2101 Constitutional Avenue Wash ington, DC 20418

A. Lerman

Dept. of Geological Sciences

Nor thwes tern University

Evanston, IL 60201

Oak Ridge National Laboratory

Central Research Library

Document Reference Section

P.0. Box $X$

Oak Ridge, TN 37830

E. Bondietti

Environmental Sciences Div. Oak Ridge National Laboratory

Oak Ridge, TN 37830

H. C. Claiborne

Oak Ridge National Laboratory

P.0. Box $X$

Oak Ridge, TN 37830 
No. of

Copies

E. H. Kob isk

Sol id State Division

Oak Ridge National Laboratory

Oak Ridge, TN 37830

W. B. White

Materials Research

Laboratory

Pennsylvania State University University Park, PA 16802

G. F. P inder

Dept. of Civil Engineering

Princeton University

Princeton, NJ 08540

J. D. Osnes

RE/SPEC

P.0. Box 725

1 Concourse Dr.

Rapid City, SD 57709

J. K. Johnstone

Sandia National Laboratories

Albuquerque, NM 87185

R. W. Lynch, Manager

Dept. 4530

Sandia National Laboratories

P.0. Box 5800

Albuquerque, NM 87185

M. A. Molecke

Nuciear Was te Exper imental

Progr ams

Sandia National Laboratories

P. 0. Box 5800

Albuquerque, NM 87185

E. J. Nowak

Sandia National Laboratories

Div is ion 5824

Albuquerque, NM 87131

J. A. Ruppen

Sandia National Laboratories

P.0. Box 5800

Albuquerque, NM 87185
No. of

Copies

Savannah River Laboratory

Reference Library

Aiken, SC 29801

J. S. Cranda 11, Director

E. I. du Pont de Nemours and Company, Inc.

Savannah River Laboratory

Aiken, SC 29801

R. G. Garvin

E. I. du Pont de Nemours and Company, Inc.

Savannah River Laboratory

P.0. Box A

Aiken, SC 29801

M. S. Plodinec

E. I. du Pont de Nemours and Company, Inc.

Savannah River Laboratory

Aiken, SC 29801

G. A. Parks

Dept. of Applied Earth Sciences

Stanford University

Stanford, CA 94305

J. 0. Blomeke

Union Carbide Corporation (ORNL)

Chemical Technology Division

P.0. Box $Y$

Oak Ridge, TN 37830

H. W. Godbee

Union Carbide Corporation (ORNL)

Chemical Technology Division

P.0. Box $Y$

Oak Ridge, TN 37830

D. B. Stewart

National Center 959

U.S. Geological Survey

Reston, VA 22092 
No. of

Copies

R. E. Cunn ingh am

Deputy Director for Fuels and Materials

U.S. Nuclear Regulatory Commission

Silver Springs, MD 20910

J. Davis

U.S. Nuclear Regulatory Commiss ion

Washington, DC 20555

J. B. Martin

Div. of Materials and Fuel Cycle Facility Licensing

U.S. Nuclear Regulatory Commiss ion

Wash ington, DC 20555

M. B. McNeil

U.S. Nuclear Regulatory Commiss ion

Washington, DC 20555

Wilste Library

U.S. Nuclear Regulatory Commission

Washington, DC 20555

F. Parker

Dept . of Env ironmen tal

Engineer ing

Vanderbilt University

Nashville, TN 37235

D. Newby

Advanced Energy Systems Division Westinghouse Electric Corp.

P.0. Box 10864

Pittsburgh, PA 15236

J. Schornhorst

Adv anced Energy Sys tems Div is ion Westinghouse Electric Corp.

P.0. Box 10864

Pittsburgh, PA 15236
No. of

Copies

ONSITE

4 DOE Richland Operations Office

J. J. Schreiber (2)

H. E. Ransom

M. W. Shupe

13 Rockwe 11 Hanford Operations

W. J. Anderson

M. J. Apted

R. A. Deju

L. R. Fitch

R. J. Gimera

R. N. Gurley

G. K. Jacobs

M. J. Kupfer

E. L. Moore

P. A. Salter

W. W. Schulz

M. J. Smith

M. I. Wood

Exxon Nuclear Company

S. J. Beard

Joint Center for Graduate Study

J. Cooper

UNC Nuclear Industries, Inc.

F. H. Blouse

5 Westinghouse Hanford Company

L. D. Bl ackburn

L. James

R. L. Knecht

J. J. McCown

W. J. Mills 
89 Pacific Northwest Laboratory

L. L. Ames

W. E. Anderson

W. F. Bonner

D. J. Bradley

L. A. Bray

D. B. Cear lock

T. D. Chikalla

R. A. Clark

M. O. Clon inger

D. G. Coles

S. D. Dahl gren

R. L. Dillon

F. H. Dove

S. K. Edler

R. P. Elmore

M. G. Foley

C. R. Hann

C. 0. Harvey

A. J. Haverfield

F. N. Hodges

J. H. Jarrett

E. A. Jenne

A. B. Johnson, Jr.

Y. B. Katayama
M. R. Kreiter

K. M. Krupka

W. L. Kuhn

J. L. McElroy

G. L. McVay

J. E. Men de 1

M. D. Merz

J. L. Nelson

R. E. Nightingale

L. R. Pederson

R. D. Peters

S. G. Pitman (30)

D. Rai

J. F. Rel yea

W. A. Ross

R. J. Serne

J. W. Shade

S. C. Slate

J. A. Stottlemyre

R. J. Strickert

J. L. Swanson

R. P. Turcotte

H. H. Van Tuyl

R. E. Westerman (5)

J. H. Westsik, Jr. Technical Information (5)

Publishing Coordination (2) 
